\title{
Pharmacologically Distinct Nicotinic Acetylcholine Receptors Drive Efferent-Mediated Excitation in Calyx-Bearing Vestibular Afferents
}

\author{
[DJ. Chris Holt, ${ }^{1,2,3}$ Kevin Kewin, ${ }^{1}$ Paivi M. Jordan, ${ }^{1}$ Peter Cameron, ${ }^{4}$ Marcin Klapczynski, ${ }^{4}$ \\ J. Michael McIntosh, ${ }^{5}$ Peter A. Crooks, ${ }^{6}$ Linda P. Dwoskin, ${ }^{7}$ and DAnna Lysakowski ${ }^{4}$ \\ ${ }^{1}$ Department of Otolaryngology, ${ }^{2}$ Department of Neurobiology and Anatomy, and ${ }^{3}$ Department of Pharmacology and Physiology, University of Rochester, \\ Rochester, New York 14642, ${ }^{4}$ Department of Anatomy and Cell Biology, University of Illinois at Chicago, Chicago, Illinois 60612, ${ }^{5}$ Department of Psychiatry, \\ University of Utah, Salt Lake City, Utah 84112, ${ }^{\circ}$ Department of Pharmaceutical Sciences, College of Pharmacy, University of Arkansas for Medical Sciences, \\ Little Rock, Arkansas 72205, and ${ }^{7}$ College of Pharmacy, University of Kentucky, Lexington, Kentucky 40536
}

Electrical stimulation of vestibular efferent neurons rapidly excites the resting discharge of calyx/dimorphic (CD) afferents. In turtle, this excitation arises when acetylcholine $(\mathrm{ACh})$, released from efferent terminals, directly depolarizes calyceal endings by activating nicotinic ACh receptors (nAChRs). Although molecular biological data from the peripheral vestibular system implicate most of the known nAChR subunits, specific information about those contributing to efferent-mediated excitation of CD afferents is lacking. We sought to identify the nAChR subunits that underlie the rapid excitation of $\mathrm{CD}$ afferents and whether they differ from $\alpha 9 \alpha 10 \mathrm{nAChRs}$ on type II hair cells that drive efferent-mediated inhibition in adjacent bouton afferents. We recorded from CD and bouton afferents innervating the turtle posterior crista during electrical stimulation of vestibular efferents while applying several subtype-selective nAChR agonists and antagonists. The $\alpha 9 \alpha 10$ nAChR antagonists, $\alpha$-bungarotoxin and $\alpha$-conotoxin RgIA, blocked efferent-mediated inhibition in bouton afferents while leaving efferent-mediated excitation in $\mathrm{CD}$ units largely intact. Conversely, 5-iodo-A-85380, sazetidine-A, varenicline, $\alpha$-conotoxin MII, and bPiDDB ( $N, N$-dodecane-1,12-diyl-bis-3-picolinium dibromide) blocked efferent-mediated excitation in CD afferents without affecting efferent-mediated inhibition in bouton afferents. This pharmacological profile suggested that calyceal nAChRs contain $\alpha 6$ and $\beta 2$, but not $\alpha 9$, nAChR subunits. Selective blockade of efferent-mediated excitation in CD afferents distinguished dimorphic from calyx afferents by revealing type II hair cell input. Dimorphic afferents differed in having higher mean discharge rates and a mean efferentmediated excitation that was smaller in amplitude yet longer in duration. Molecular biological data demonstrated the expression of $\alpha 9$ in turtle hair cells and $\alpha 4$ and $\beta 2$ in associated vestibular ganglia.

Key words: ACh; $\alpha 6$ nAChR; $\alpha 9$ nAChR; calyx; vestibular afferent; vestibular efferent

\section{Introduction}

Cholinergic vestibular efferent neurons (VENs) originate bilaterally in the dorsal brainstem and send axons via cranial nerve VIII to innervate the vestibular end organs (Meredith, 1988; Lysakowski and Goldberg, 2004). Within the neuroepithelium, VENs

Received Aug. 13, 2014; revised Jan. 15, 2015; accepted Jan. 16, 2015

Author contributions: J.C.H., P.M.J., P.C., M.K., J.M.M., P.A.C., L.P.D., and A.L. designed research; J.C.H., K.K., P.M.J., P.C., M.K., and A.L. performed research; J.C.H., K.K., P.M.J., P.C., M.K., and A.L. analyzed data; J.C.H., P.M.J., J.M.M., P.A.C., L.P.D., and A.L. wrote the paper.

This work was supported by NIH/NIDCD Grants R01DC008981 (J.C.H.), R01DC02521 and DC02058 (A.L.), GM48677 and GM103801 (J.M.M.), UL1 TR000117 and U19 DA017548 (L.P.D., P.A.C.), and P30-DC005409 (Center for Communicative and Navigational Sciences, University of Rochester). We thank Lila Yang for help in tissue acquisition, Linda Callahan in the University of Rochester Medical Center Confocal and Conventional Microscopy Core for her help in acquisition of IHC images, Dr. Paul Allen for advice on statistical analyses, and Dr. Sophie Gaboyard and Steven D. Price for their IHC expertise. Drs. Jay Goldberg, Alan Brichta, and Rebecca Lim commented on a previous version of the manuscript.

The authors declare no competing financial interests.

Correspondence should be addressed to J. Chris Holt, Department of Otolaryngology, University of Rochester, 601 Elmwood Avenue, Box 603, Rochester, NY 14642.E-mail: joseph_holt@urmc.rochester.edu.

DOI:10.1523/JNEUROSCI.3388-14.2015

Copyright $\odot 2015$ the authors $\quad 0270-6474 / 15 / 353625-19 \$ 15.00 / 0$ undergo extensive branching to give rise to many presynaptic varicosities that appose hair cells and afferent processes (Smith and Rasmussen, 1968; Sans and Highstein, 1984; Lysakowski and Goldberg, 1997; Purcell and Perachio, 1997). Electrical stimulation of VENs rapidly inhibits and/or excites the resting discharge of most vestibular afferents (Goldberg and Fernández, 1980; Rossi et al., 1980; Highstein and Baker, 1985; Brichta and Goldberg, 2000b). A preponderance of pharmacological data suggests that the release of acetylcholine (ACh) and activation of nicotinic ACh receptors (nAChRs) underlie these rapid inhibitory and excitatory responses (Guth et al., 1998; Holt et al., 2011).

Efferent-mediated inhibition of vestibular afferents is initiated by the activation of $\alpha 9 \alpha 10 \mathrm{nAChRs}$ in type II hair cells (Holt et al., 2001, 2006b). Calcium influx through $\alpha 9 \alpha 10$ nAChRs activates calcium-dependent potassium channels (SKs), resulting in hair cell hyperpolarization, reduction in transmitter release, and inhibition of afferent firing (Oliver et al., 2000; Elgoyhen et al., 2001; Weisstaub et al., 2002). Consistent with such mechanisms, efferent-mediated inhibition is blocked by $\alpha 9 \alpha 10 \mathrm{nAChR}$ antagonists, including 3-tropanylindole-3-carboxylate [ICS-205,390 
(ICS)] and $\alpha$-bungarotoxin ( $\alpha$ BTX), and is converted to excitation by SK blockers. Furthermore, convergence of RT-PCR, in situ hybridization (ISH), and immunohistochemical (IHC) data confirms the $\alpha 9 \mathrm{nAChR}$ subunit is expressed by type II hair cells (Hiel et al., 1996; Lustig et al., 1999; Holt et al., 2001; Kong et al., 2006).

Efferent-mediated excitation of vestibular afferents is attributed to enhancement of transmitter release from type II hair cells (Rossi et al., 1980; Bernard et al., 1985; Sugai et al., 1991) or direct afferent depolarization (Highstein and Baker, 1985; Holt et al., 2006b). Both forms of excitation are potently blocked by the $\mathrm{nAChR}$ antagonist dihydro- $\beta$-erythroidine (DH $\beta \mathrm{E})$, but show a limited sensitivity to $\alpha 9 \alpha 10 \mathrm{nAChR}$ antagonists (Guth et al., 2002; Holt et al., 2003, 2006b). The simplest interpretation of these pharmacological data is that efferent-mediated afferent excitation uses nAChRs distinct from $\alpha 9 \alpha 10$. To this end, ISH and RT-PCR studies have implicated a number of other nAChR subunits in vestibular ganglia and end organs (Wackym et al., 1995; Zoli et al., 1995; Hiel et al., 1996; Anderson et al., 1997). However, labeling with $\alpha 9$ antibodies and $\alpha \mathrm{BTX}$, as well as recent pharmacological data, suggests that afferent processes also express $\alpha 9 \alpha 10$ nAChRs (Ishiyama et al., 1995; Wackym et al., 1995; Dailey et al., 2000; Luebke et al., 2005; Yu et al., 2014).

In this paper, electrophysiological recordings were acquired from turtle posterior crista afferents in response to electrical stimulation of efferent fibers during the application of selective nAChR compounds. The goals were as follows: (1) to resolve whether $\alpha 9 \alpha 10 \mathrm{nAChRs}$ are involved in efferent-mediated excitation of calyx/dimorphic (CD) afferents; (2) to identify what other nAChR subunits play a role; and (3) to determine whether calyx and dimorphic afferents differ in their responses to efferent stimulation.

\section{Materials and Methods}

Tissue preparation. Red-eared slider turtles (Trachemys scripta elegans, $100-500 \mathrm{~g}, \sim 7-18 \mathrm{~cm}$ carapace length) of either sex were deeply anesthetized with sodium pentobarbital. Upon loss of reflexes, turtles were decapitated and the head was split along the mid-sagittal plane. The two halves were immediately placed in an oxygenated control solution containing the following (in mM): $105 \mathrm{NaCl}, 4 \mathrm{KCl}, 0.8 \mathrm{MgCl}_{2}, 2 \mathrm{CaCl}_{2}, 25$ $\mathrm{NaHCO}_{3}, 2 \mathrm{Na}$-pyruvate, 0.5 glutamine, 10 glucose, $\mathrm{pH}$ 7.2-7.3, during continuous bubbling with $95 \% \mathrm{O}_{2} / 5 \% \mathrm{CO}_{2}$. Only the left half was used for nerve recordings (Holt et al., 2006a,b). For RNA-DNA studies, vestibular end organs and ganglia were extracted from both halves, dissected, and transferred to ice-cold RNAlater (Ambion). Inner ear tissues intended for protein studies were placed in $1 \times$ Tris-buffered saline (TBS) containing a protease inhibitor mixture (catalog \#P2714, SigmaAldrich) and immediately frozen on dry ice. For ISH and IHC procedures, vestibular tissue was prepared by either extracting whole labyrinths from the inner ear and drop-fixing in $4 \%$ paraformaldehyde (PFA), or perfusing the labyrinth with $4 \%$ PFA, $1 \%$ acrolein, $1 \%$ picric acid, and $5 \%$ sucrose in control solution before extraction. The latter fixation was used for ISH and immunohistochemistry for nAChR subunits. All procedures involving animals were in accordance with recommendations made by NIH's Guide for the Care and Use of Laboratory Animals and approved by the University Committee for Animal Resources at the University of Rochester and by the Institutional Animal Care and Use Committee at the University of Illinois at Chicago.

Nerve recording setup. Methods were similar to those described in previous papers (Holt et al., 2006a,b, 2007). All neurophysiological procedures were conducted at room temperature $\left(\mathrm{RT} ; 21-23^{\circ} \mathrm{C}\right)$. The brain was blocked transversely between the levels of the trigeminal and glossopharyngeal nerves. These nerves and surrounding bone were then removed to provide direct access to the bony plate over the posterior ampulla. A small fenestra was made to gain access to the main posterior ampullary nerve and its branches to each hemicrista. Several layers of connective tissue covering the nerve were then removed with a fine tung- sten hook. The half-head was mounted in a recording chamber and the posterior ampullary nerve was continuously superfused with oxygenated control solution from a gravity-fed pipette capable of delivering solutions at $3-4 \mu \mathrm{l} / \mathrm{s}$ from any one of six $10 \mathrm{ml}$ reservoirs.

Borosilicate microelectrodes (40-100 $\mathrm{M} \Omega$; Sutter Instruments) were filled with $3 \mathrm{M} \mathrm{KCl}$ and connected to a preamplifier (Biomedical Engineering), which neutralized microelectrode capacitance by driving the shield of the input cable. Microelectrodes were advanced in $5 \mu \mathrm{m}$ steps with a Burleigh Inchworm drive mounted on a three-axis micromanipulator (EXFO Burleigh Products). Recordings were made from the posterior ampullary nerve just as it bifurcates to innervate the two hemicristae (Holt et al., 2006a,b).

Efferent stimulation. Electrical stimulation of efferent fibers was used to classify afferents (Brichta and Goldberg, 2000b; Holt et al., 2006b). All efferent fibers destined for the posterior crista, but none of the afferents, travel in a small nerve bundle, or cross-bridge, running between the anterior and posterior divisions of the VIIIth nerve (Fayyazuddin et al., 1991). Access to the bundle was made possible by removing a bony section of the roof of the mouth just rostral to the lagena. To avoid muscle contractions during stimulation, jaw muscles were removed and the facial nerve was severed at its bony entrance into the middle ear. Efferent stimulating electrodes were constructed from Teflon-coated silver wires (AG10T, Medwire), insulated except for the last $0.5 \mathrm{~mm}$ chlorided tip. One electrode was placed on the cross-bridge while a second electrode was placed on nearby bone. Electrical stimuli consisted of trains of $100 \mu \mathrm{s}$ constant-current shocks delivered from a stimulus isolator (model A360, World Precision Instruments) to the two electrodes. The cross-bridge electrode was the cathode. Efferent shock artifacts were canceled off-line after computing an average artifact and subtracting it from the corresponding records.

Data acquisition and computer processing. Data acquisition and efferent stimuli were controlled using a PC with custom-made Spike2 scripts and micro1401 interface (Cambridge Electronic Design). Microelectrode signals were low-pass filtered at $1 \mathrm{kHz}$ (four-pole Bessel; model 432, Wavetek) and sampled at $10 \mathrm{kHz}$ by a 12-bit analog-to-digital converter. Delivery of efferent shock trains was controlled from a digital-output port. Spike2 data files were first exported as general text files and then processed using custom macros written in IgorPro 6.36 (WaveMetrics).

Physiological testing and response analysis. In all afferent recordings, $2-5 s$ of background activity were recorded before our standard efferent stimulus, a shock train consisting of 20 shocks at $200 \mathrm{~Hz}$, was delivered to the efferent nerve fibers in the cross-bridge. Several trains were presented and shock amplitude was adjusted so as to provide a clear response devoid of any antidromic activation. Stimulus thresholds (Ts) typically ranged from 15 to $100 \mu \mathrm{A}$ and maximal current intensities ranged from 40 to $300 \mu \mathrm{A}(2-3 \times T)$. Mean spike responses to efferent stimulation were calculated by averaging $10-25$ trials. The result was displayed as an average response histogram. The mean amplitude of efferent-mediated excitation or inhibition was calculated from the first $100 \mathrm{~ms}$ segment of the average response histogram immediately following the efferent shock train (Brichta and Goldberg, 2000b). Intertrial intervals were 3-5 s to allow afferent discharge to return to prestimulus values before delivery of the next efferent shock train.

Efferent-mediated effects on hair cells alter ongoing quantal activity in the afferent nerve fiber. Characterization of such activity during efferent stimulation is instructive in distinguishing efferent actions in hair cells versus direct efferent actions on afferents (Rossi et al., 1994; Holt et al., $2006 a, b)$. To characterize quantal activity, we relied on shot-noise theory, which assumes that the shapes of individual quantal events are stereotyped and their occurrence follows Poisson statistics. Following Rice's (1944) extension of Campbell's theorem, the first three central moments [i.e., mean $\left(\lambda_{1}\right)$, variance $\left(\lambda_{2}\right)$, and skew $\left(\lambda_{3}\right)$ ], are related to the quantal rate (qrate, $\xi$ ), quantal size (qsize, $h$ ), and the shape of individual quanta $[f(t), t \geq 0]$ using the following equation (Eq. 1):

$$
\lambda_{n}=\xi\left\langle h^{n}\right\rangle I_{n}
$$

Here and in subsequent equations, angle brackets indicate expected values, superscripts are exponents, and subscripts are indices. $I_{1}, I_{2}$, and $I_{3}$ are integrals of the following form (Eq. 2): 
Table 1. List of cholinergic drugs used in this study

\begin{tabular}{|c|c|c|c|c|}
\hline Compound $^{a}$ & $\begin{array}{l}\text { nAChR subunit } \\
\text { selectivity }^{b}\end{array}$ & $\begin{array}{l}\mathrm{EC}_{50} / \mathrm{IC}_{50} \\
\text { range }(\mathrm{nM})^{\mathrm{c}}\end{array}$ & $\begin{array}{l}\text { Range in this study } \\
(\mu \mathrm{M})^{d}\end{array}$ & References $^{e}$ \\
\hline \multicolumn{5}{|l|}{ Agonists } \\
\hline Cytisine & $\alpha 4 \beta 2^{*}, \alpha 6 \beta 2^{*}$ & $2-200$ & $0.3-1$ & Capelli et al., 2011; Marks et al., 2010; Papke et al., 2011 \\
\hline 5-iodo & $\alpha 4 \beta 2, \alpha 6 \beta 2^{*}, \alpha 3 \beta 4$ & $76-794$ & $0.01-3$ & Capelli et al., 2011; Carbone et al., 2009 \\
\hline SazA & $\alpha 4 \beta 2, \alpha 6 \beta 2^{*}$ & $0.2-36$ & $0.01-3$ & Capelli et al., 2011; Xiao et al., 2006; Zwart et al., 2008 \\
\hline Varenicline & $\alpha 4 \beta 2^{*}, \alpha 6 \beta 2^{*}, \alpha 7 \mathrm{~h}$ & $1.6-334$ & $0.1-0.3$ & Capelli et al., 2011; Coe et al., 2005; Papke et al., 2011; Peng et al., 2013 \\
\hline \multicolumn{5}{|l|}{ Antagonists } \\
\hline$\alpha$-CtxMII & $\alpha 3 \beta 2^{*}, \alpha 6 \beta 2^{*}, \alpha 3 \beta 4$ & $0.5-316$ & 2 & Capelli et al., 2011; Cartier et al., 1996; Harvey et al., 1997; McClure-Begley et al., 2012; Mclntosh et al., 2004 \\
\hline$\alpha$-CtxRglA & $\alpha 9 \alpha 10$ & $1.5-490$ & $0.333-1.67$ & Azam and McIntosh, 2012; Ellison et al., 2006; Vincler et al., 2006 \\
\hline bPiDDB & $\alpha 3 \beta 4^{*}, \alpha 4 \beta 4, \alpha 6 \beta 2^{*}$ & $2-700$ & $0.1-3$ & Dwoskin et al., 2008; Papke et al., 2008; Rahman et al., 2008 \\
\hline $\mathrm{DH} \beta \mathrm{E}$ & $\alpha 4 \beta 2, \alpha 6 \beta 2^{*}, \alpha 4 \beta 4$ & $10-380$ & $0.1-1$ & $\begin{array}{l}\text { Chavez-Noriega et al., 1997; Harvey and Luetje, 1996; Papke et al., 2008; Iturriaga-Vásquez et al., 2010; Capelli } \\
\text { et al., } 2011\end{array}$ \\
\hline MLA & $\alpha 7^{*}, \alpha 9^{*}, \alpha 4 \beta 2, \alpha 6 \beta 2^{*}$ & $0.3-631$ & $0.1-1$ & Verbitsky et al., 2000; Evans et al., 2003; Capelli et al., 2011; Mogg et al., 2002 \\
\hline
\end{tabular}

${ }^{a}$ Name of cholinergic agonist or antagonist.

${ }^{b}$ Selectivity for specificnAChR subunits or subunit combinations as predicted from expression studies in Xenopus oocytes, HEK cells, hair cells, or tissue where contributing subunits were known. The asterisk (*) indicates that $\mathrm{nAChR}$ can include additional subunits (e.g. $\alpha 7 \beta 2, \alpha 9 \alpha 10)$; i indicates homomeric.

'Range of nanomolar concentrations needed to achieve $50 \%$ of the maximal activation or maximal inhibition, respectively.

${ }^{d}$ Range of micromolar concentrations used in the current study.

${ }^{e}$ References denote subunit selectivity and measurements of sensitivity.

$$
I_{n}=\int_{0}^{\infty} f^{n}(t) d t
$$

where $f(t)$ is normalized to a peak value of unity. In this paper, ensemble means $\left(\lambda_{1}\right)$ were obtained from the original voltage records. Ensemble variances $\left(\lambda_{2}\right)$ and ensemble skews $\left(\lambda_{3}\right)$ were extracted after first digitally high-pass filtering (single-pole, corner frequency of $1000 \mathrm{rad} / \mathrm{s}, 159 \mathrm{~Hz}$ ) the original records. When using filtered data, $f(t)$ in Equation 2 was normalized before filtering.

Modulation of either qsize or qrate can result in variance changes. We exploited the relation between $\lambda_{3}$ and $\lambda_{2}$ to distinguish between the two modulations during efferent stimulation, where a variation in qrate leads to a linear relation as expressed in the following equation (Eq. 3):

$$
\lambda_{3}=\left(h I_{3} / I_{3}\right) \lambda_{2} \text {. }
$$

Meanwhile, qsize variation, with other parameters remaining unchanged, gives a nonlinear relation as expressed in the following equation (Eq. 4):

$$
\lambda_{3}^{2}=\left(I_{3}^{2} / \xi I_{2}^{3}\right) \lambda_{2}^{3}
$$

Residual variance (Rvar), defined as the variance remaining once quantal activity has been suppressed (i.e., $\lambda_{3}=0$ ), is attributed to instrumental noise (Holt et al., 2007; Goldberg and Holt, 2013). The total ensemble variance was corrected for instrumental noise by subtracting Rvar. To estimate Rvar, we obtained the ensemble skew-variance relation from high-pass records for points within the first second after delivery of the efferent shock train. A linear regression of these points was extrapolated to zero skew to obtain Rvar. Using the extrapolation to estimate the Rvar was more reliable in afferents where there was an efferent-mediated decrease in $\lambda_{2}$ and $\lambda_{3}$. We then plotted the ensemble skew against the corrected ensemble variance in double-logarithmic coordinates. When fitted with a log-log regression line, slopes near 1 (i.e., unity) were indicative of changes in qrate whereas slopes near 1.5 were interpreted as changes in qsize (Holt et al., 2006a,b).

To study the effects of efferent stimulation on synaptic activity during intracellular recordings, two different approaches were used: (1) QX-314 [2-(triethylamino)- $N$-(2,6-dimethylphenyl) acetamide; $40 \mathrm{~mm}$, a charged lidocaine derivative, was added to the micropipette solution to block spikes in the recorded afferent; or (2) ensemble measurements were made after spikes were digitally removed off-line and replaced with a blank interval. In the latter approach, sufficient prespike and postspike intervals were also blanked so that estimates of synaptic variance were not influenced by the spike and subsequent afterhyperpolarization. Intracellular recordings were analyzed only if the membrane potential was more negative than $-40 \mathrm{mV}$. To avoid contamination from shock artifacts, mean values of voltage and variance were calculated from an $80 \mathrm{~ms}$ segment taken 20 $\mathrm{ms}$ after termination of the efferent shock train. Ensemble measurements were tabulated from 10 to 25 efferent shock presentations.

Solutions. $\alpha$-BTX, DH $\beta$ E, 1,1-dimethyl-4-piperazinium (DMPP), ICS, and QX-314 were obtained from Sigma-Aldrich. 5-iodo-A-85380 (5-iodo), cytisine, methyllycaconitine (MLA), sazetidine-A (SazA), and varenicline were from Tocris Cookson. QX-314 was dissolved in $3 \mathrm{M} \mathrm{KCl}$ and stored as frozen $40 \mathrm{~mm}$ aliquots. All other drugs were prepared as concentrated stock solutions in ultrafiltered water, which were then added to the control solution to achieve the desired concentrations before each experiment. $\alpha$-Conotoxin RgIA ( $\alpha$-CtxRgIA), $\alpha$-conotoxin MII ( $\alpha$-CtxMII), and bPiDDB ( $N, N$-dodecane-1,12-diyl-bis-3-picolinium dibromide) were synthesized as previously described (Cartier et al., 1996; Ayers et al., 2002; Vincler et al., 2006) and also obtained from Tocris Bioscience. Most pharmacological agents usually took $30 \mathrm{~s}$ to 2 min to begin acting and another 2-5 min to reach maximal effect. Washout times were variable and could be $>10 \mathrm{~min}$. Application (i.e., wash-in) and wash-out times were frequently longer for peptide toxins presumably due to their larger molecular weights. Drug reversibility for most compounds was demonstrated within a single afferent recording session with the exception of 5-iodo, SazA, and varenicline. Recovery from SazA was demonstrated with subsequent recordings in the same preparation, whereas reversibility from 5-iodo and varenicline was not observed. Receptor selectivity, measures of potency $\left(\mathrm{IC}_{50}\right)$, and the range of concentrations used in this study are shown in Table 1.

Statistical procedures. All statistical analyses were done in Graph Pad Prism (GraphPad Software). Unless otherwise stated, values are expressed as means \pm SEM. One-sample $t$ test was used to evaluate whether means differed from zero. Drug effects were evaluated by a paired $t$ test. An unpaired $t$ test was used to determine whether the amplitude and duration of efferent-mediated excitation as well as the background discharge rate differed between calyx and dimorphic afferents.

IHC studies. Freshly fixed semicircular canal cristae were placed in $30 \%$ sucrose for $\geq 1 \mathrm{~h}$ at $4^{\circ} \mathrm{C}$, and then embedded in a gelatin mold $(12 \%$ gelatin prepared in $30 \%$ sucrose) and chilled at $4^{\circ} \mathrm{C}$. Upon solidification, the gelatin block was mounted on the stage of a freezing sliding microtome and 35-40 $\mu \mathrm{m}$ frozen sections were subsequently cut and transferred to a collection vial. The collection vial was warmed to dissolve the 
gelatin and tissue sections were rinsed with $0.1 \mathrm{M} \mathrm{PB}$. For nAChR labeling, preliminary treatments included a $10 \mathrm{~min}$ incubation in an aqueous $1 \% \mathrm{Na}$ borohydride solution, and $1 \mathrm{~h}$ in a blocking solution ( $1 \%$ teleost fish gelatin, $1 \%$ bovine serum albumin, and $0.5 \%$ Triton X-100 in PBS). For other IHC processing, tissue was blocked in $5 \%$ normal donkey serum (Jackson Immunoresearch) prepared in 0.5\% Triton X-100/0.1 M PB. After block, the tissue sections were then incubated 16-48 h with primary antibodies (see Antibodies). Following several rounds of $0.1 \mathrm{M}$ $\mathrm{PB}$ washes, sections were incubated with Alexa Fluor-conjugated secondary antibodies (Invitrogen) at 1:200-1:500 dilution in $0.1 \mathrm{M} \mathrm{PB}$ for 2-3 h in the dark at RT. Sections were again washed several times with $0.1 \mathrm{M} \mathrm{PB}$ and reacted with DAPI (1:1000 of a $1 \mathrm{mg} / \mathrm{ml}$ solution; Sigma-Aldrich) for 5 min followed by a brief wash in distilled $\mathrm{H}_{2} \mathrm{O}$. Using an eyelash probe, final tissue sections were transferred to Plus Slides (Fisher Scientific) and coverslipped with SlowFade Gold (Invitrogen), Mowiol (Calbiochem), or Vectashield (Vector Laboratories). Stained cristae were visualized on an Olympus FV1000 (Olympus America) in the University of Rochester Medical Center Confocal and Conventional Microscopy Core or on a Zeiss LSM 510 META (Carl Zeiss) laser scanning confocal microscope at the University of Illinois at Chicago. Confocal images were captured with Olympus Fluoview or Zeiss LSM 5 Image Browser proprietary software and exported as TIFF files. Sizing and labeling of digital TIFF images were done with Adobe Photoshop and Adobe Illustrator. Efferent varicosities on hair cells and calyx-bearing afferents were quantified manually by rotating three-dimensional image stacks following isosurface reconstruction and volume rendering in the image analysis software Amira (FEI).

Antibodies. Antibodies to choline acetyltransferase (ChAT), the ratelimiting enzyme in ACh synthesis (Millipore, AB144P, lot JC1618187; 1:100) were used to label efferent fibers and varicosities (Ohno et al., 1993; Kong et al., 1994; Popper et al., 2002; Jordan et al., 2013). Calretinin (Millipore, AB5054, lot LV1552190; 1:1000) was used to label type II hair cells near the planum, calyx and dimorphic afferents in the central zone (CZ), and bouton afferents near the torus region (Monk and Peterson, 1995; Huwe et al., 2011). Monoclonal antibodies to myosin VIIA (Developmental Studies Hybridoma Bank, 138-1C; 1:50-1:100) and SV2 (Developmental Studies Hybridoma Bank; SV2 conc.; 1:500-2000) were developed by Dana Jo Orten and K. Buckley, respectively. Both were obtained from the Developmental Studies Hybridoma Bank developed under the auspices of the National Institute of Child Health and Human Development and maintained by the University of Iowa, Department of Biology, Iowa City, Iowa. Anti-myosin VIIA was used to label hair cells and anti-SV2 was used to label synaptic vesicles in efferent varicosities (Hasson et al., 1997; Pujol et al., 2014). The affinity-purified rabbit anti- $\alpha 9$ nAChR subunit antibody (IL-308; $1: 100-1: 1000$ ) used in this study was produced commercially (Covance Research Products) against a 16 aa peptide sequence (SQLSRNRNNDSDLKKK) located in the large and poorly conserved intracellular loop between membrane spanning regions III and IV of cloned turtle $\alpha 9 \mathrm{nAChR}$ subunit (accession number AY768813). A cysteine attached at the $\mathrm{N}$ terminus of the peptide permitted conjugation to keyhole limpet hemocyanin carrier. Specificity and sensitivity of the IL-308 antibody were verified with appropriate binding to different amounts of the $\alpha 9 \mathrm{nAChR}$ subunit peptide solution $(0.1,0.5$, $1 \mu \mathrm{g}$ ) immobilized in nitrocellulose membranes (data not shown). Negative controls included both deletion of the primary antibodies and, when available, a preabsorption control done with peptide antigen.

$I S H$. Oligonucleotide primers were generated from the turtle $\alpha 9$ nAChR gene and the partial coding sequences of the turtle $\alpha 4$ and $\beta 2$ nAChR genes that we cloned (accession numbers AY768813, EU526107, EU526108). Fixed turtle cristae were either reacted as whole mounts or as $40 \mu \mathrm{m}$ free-floating sections cut on a vibratome. Tissue was dehydrated and rehydrated through a graded alcohol series $(50,70,100,70,50,25 \%$ $\mathrm{EtOH})$. Permeabilization was accomplished with $0.5 \%$ Triton X-100 overnight at $4^{\circ} \mathrm{C}$ and subsequently with proteinase $\mathrm{K}(0.6 \mathrm{mg} / \mathrm{ml})$ treatment for $20 \mathrm{~min}$ at $37^{\circ} \mathrm{C}$. The enzyme was neutralized with glycine $(0.1$ M). The samples were postfixed in 4\% PFA and acetylated in acetic anhydride $(0.25 \%)$ for $10 \mathrm{~min}$. All preincubation and incubation steps were done on a rotator inside a hybridization oven. A preincubation with hybridization buffer $(4 \times$ SSC, $10 \%$ dextran sulfate, $1 \%$ Denhard's solu- tion) was done for $1 \mathrm{~h}$ at $52^{\circ} \mathrm{C}$. Approximately $100 \mathrm{ng}$ of digoxigeninlabeled riboprobes were then hybridized overnight at $52^{\circ} \mathrm{C}$. Nonbinding probes were rinsed using $2 \times \mathrm{SSC}$ at $37^{\circ} \mathrm{C}$ for $5 \mathrm{~min}$, three times with $60 \%$ formamide deionized in $0.2 \times \mathrm{SSC}$ at $37^{\circ} \mathrm{C}$ for $5 \mathrm{~min}$, and two times in $2 \times$ $\mathrm{SSC}$ at RT. An RNaseA ( $20 \mathrm{ng} / \mathrm{ml})$ treatment was next performed for 30 min at $37^{\circ} \mathrm{C}$ to digest excess single-strand RNA. After a $1 \mathrm{~h}$ blocking step at RT, the tissue was incubated with alkaline-phosphatase-conjugated sheep anti-digoxigenin antibody (Roche Molecular Biochemicals) at a 1:200 dilution in blocking solution overnight at $4^{\circ} \mathrm{C}$. Tissue was washed four times for $10 \mathrm{~min}$ with alkaline phosphatase buffer (Tris $100 \mathrm{~mm}$, $\mathrm{NaCl} 150 \mathrm{~mm}$ ), pH 7.5. Preincubation in detection buffer (Tris $100 \mathrm{~mm}$, $\mathrm{NaCl}, 150 \mathrm{~mm}, \mathrm{MgCl} 250 \mathrm{~mm}$ ), $\mathrm{pH}$ 9.5, was first performed for $2 \mathrm{~h}$, and then levamisole (2 mM; Sigma-Aldrich) was added for $30 \mathrm{~min}$. The samples were reacted with NBT/BCIP color substrate (Roche Molecular Biochemicals) in the dark for $4 \mathrm{~h}$ at RT, and subsequently overnight at $4^{\circ} \mathrm{C}$. Tissue was rinsed with alkaline phosphatase buffer (Tris $100 \mathrm{~mm}, \mathrm{NaCl}$ $150 \mathrm{~mm}$ ), pH 7.5. Some end organs were plastic-embedded for subsequent semithin sectioning at $4 \mu \mathrm{m}$. Sections were then mounted in glycerol, coverslipped, and examined and photographed on an Olympus light microscope.

Western blot for $\alpha 9 n A C h R$ subunit. Turtle inner ear tissue homogenate ( $45 \mu \mathrm{g}$ of protein) was mixed with $5 \times$ SDS loading buffer containing 2.5 M urea. Samples were denatured under two different conditions: $100^{\circ} \mathrm{C}$ for $5 \mathrm{~min}$ or $37^{\circ} \mathrm{C}$ for $15 \mathrm{~min}$. Each yielded a single band. After brief centrifugation, samples were loaded on a $4-20 \%$ Tris- $\mathrm{HCl}$ gel, and a molecular weight marker (Biorad) was used as a protein standard. Electrophoresis was performed in Tris/SDS/glycine buffer at $120 \mathrm{~V}$, until bromophenol blue dye migrated out of the gel. The gel was placed together with nitrocellulose membrane (Biorad) in an electroblot unit. The transfer was performed in Tris/glycine $/ 20 \%$ methanol buffer overnight at $35 \mathrm{~V}$, at $4^{\circ} \mathrm{C}$. After transfer, the membrane was stained with Ponceau stain (Sigma-Aldrich) to visualize lanes, photographed, and then washed with $1 \times$ TBS until the stain was removed. The membrane was incubated in $5 \%$ nonfat milk solution in $1 \times$ TBS for $2-4 \mathrm{~h}$ to block nonspecific binding. After two $10 \mathrm{~min}$ washes in $1 \times \mathrm{TBS}$, the membrane was incubated overnight at $4^{\circ} \mathrm{C}$ in an affinity-purified antibody solution (1:1000 dilution in $1 \times$ TBS with $1 \%$ BSA). The membrane was washed three times with $1 \times 0.05 \%$ TBS-Tween, and then incubated in secondary antibody solution (goat-anti-rabbit-HRP, 1:30,000 dilution in $1 \times 0.025 \%$ TBS-Tween) for $1 \mathrm{~h}$. The membrane was washed $5 \times 10 \mathrm{~min}$ in $1 \times 0.05 \%$ TBS-Tween, incubated in enhanced chemiluminescence detection reagents (GE Healthcare), wrapped in transparent plastic wrap and exposed to Hyperfilm (GE Healthcare).

To verify the specificity of the bands, preabsorption controls were done on the same nitrocellulose membranes, which were stripped with a freshly prepared stripping buffer $(65 \mathrm{~mm}$ Tris- $\mathrm{HCl}, \mathrm{pH} 6.8,2 \%$ SDS, $0.7 \% \beta$-mercaptoethanol). Membranes were incubated in this buffer for $25 \mathrm{~min}$ at $55^{\circ} \mathrm{C}$, with occasional vigorous stirring. The membrane was washed $3 \times 10$ min with $1 \times 0.05 \%$ TBS-Tween, then $3 \times 5 \mathrm{~min}$ in $1 \times$ TBS. After these washes, we used the identical blot protocol described above from the point of the blocking step. In this instance, however, $3 \mu \mathrm{g}$ of purified antibody was mixed with $30 \mu \mathrm{g}$ of the $\alpha 9$ peptide antigen and incubated at RT for $1 \mathrm{~h}$. The membrane was probed with this solution overnight and processed as described above.

\section{Results}

Based on hair cell morphology, the turtle posterior crista has been partitioned into a central zone $(\mathrm{CZ})$ and a peripheral zone (PZ; Brichta and Peterson, 1994; Brichta and Goldberg, 2000a). Type II hair cells and their bouton afferent innervation are distributed throughout the crista in both the PZ and CZ, whereas type I hair cells, innervated by calyx or dimorphic afferents (CD), are restricted to the CZ (Fig. 1, top box). Bouton afferents may be further subdivided into BT, BM, and BP afferents on the basis of whether they terminate near the torus (BT), middle (BM), or planum (BP) regions, respectively. For this study, extracellular and intracellular sharp electrode recordings were made from BT, $\mathrm{BM}$, and $\mathrm{CD}$ afferents innervating the turtle posterior crista dur- 


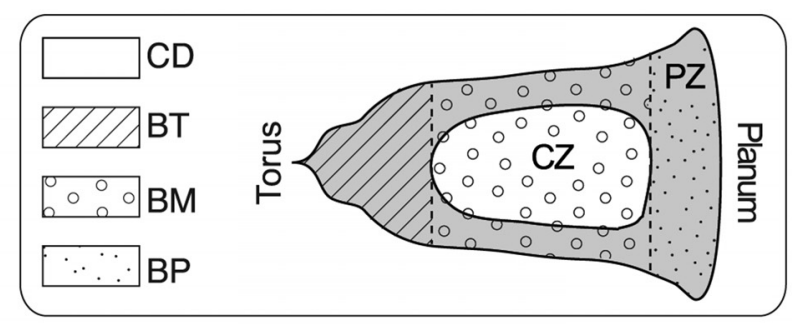

A

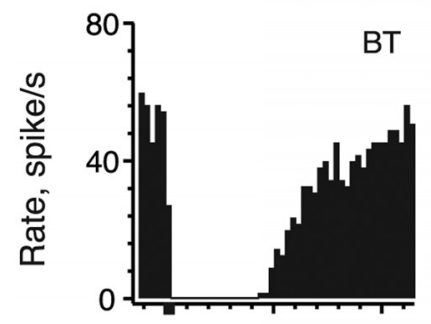

C

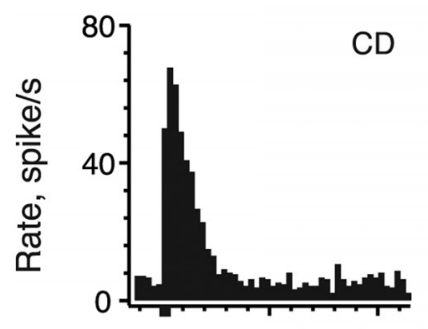

E

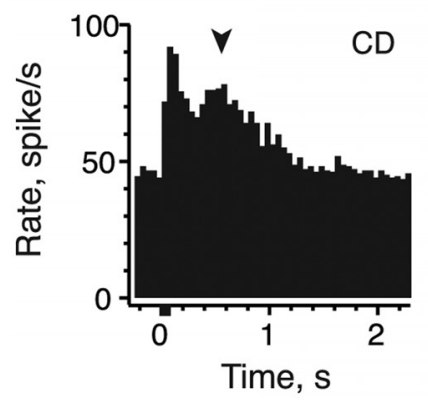

B

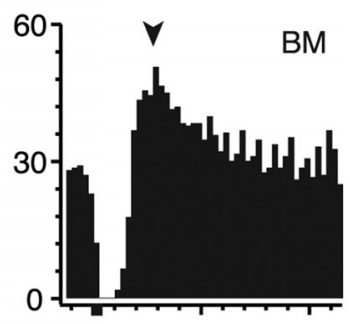

D

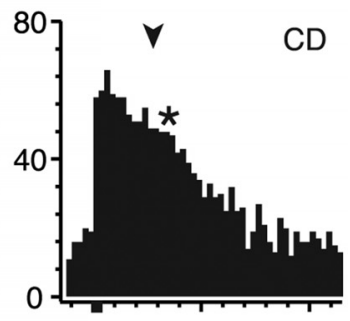

F

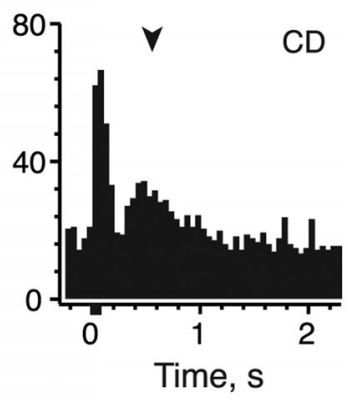

Figure 1. Effects of efferent stimulation on afferent discharge vary with unit subclass. Schematic in top panel shows the relative location of bouton (BT, BM, BP) and calyx-bearing (CD) afferents within the $C Z$ and $P Z$ of the turtle hemicrista. $\boldsymbol{A}-\boldsymbol{F}$, Average response histograms generated from extracellular recordings in $\mathrm{BT} / \mathrm{BM}(\boldsymbol{A}, \boldsymbol{B})$ and $\mathrm{CD}$ afferents $(\boldsymbol{C}-\boldsymbol{F})$ during activation of efferent fibers. Efferent shock trains (20 shocks at 200/s, black bar at $t=0$ ) were delivered every $3-5 \mathrm{~s}$. Total number of shock trains varied for each unit $(\boldsymbol{A}, 11 ; \boldsymbol{B}, 39 ; \boldsymbol{C}, 41 ; \boldsymbol{D}, 20$; $\boldsymbol{E}, 38 ; \boldsymbol{F}, 36)$. Second excitatory bump in $C D$ afferent is demarcated with an asterisk. Arrowheads indicate the temporal alignment of PIE in a BM afferent with secondary excitatory peaks in CD afferents.

ing electrical stimulation of vestibular efferents. As the recording site is located within $250 \mu \mathrm{m}$ of the neuroepithelium, we monitored both afferent discharge and underlying synaptic potentials. In a total sample of 434 afferent recordings (216 CD, 95 BT, 123 $\mathrm{BM})$, we examined efferent-mediated spike responses in 269 units (137 CD, 56 BT, 76 BM) and synaptic events in 165 units (79 $\mathrm{CD}, 39 \mathrm{BT}, 47 \mathrm{BM})$. We did not include recordings from $\mathrm{BP}$ afferents in this study, as their responses to efferent stimulation were small and their thin axons were more difficult to record from for extended periods of time.
Afferent responses to efferent stimulation differ between bouton and $\mathrm{CD}$ afferents

Responses of turtle crista afferents to efferent stimulation are related to afferent morphology and location within the crista neuroepithelium (Brichta and Goldberg, 2000a,b; Holt et al., 2006b). We exploited this relationship to categorize each afferent's response to efferent stimulation as belonging to one of three general afferent subclasses (i.e., BT, BM, and CD). Although there is some heterogeneity in response amplitude and duration within each subclass, it was primarily the overall response shape that governed the categorization (Brichta and Goldberg, 2000b; Holt et al., 2006b). Exemplars from each subclass are shown in Figure 1. Responses of BT afferents to repeated efferent shock trains ( 20 shocks at 200/s) were characterized by a profound inhibition of the resting discharge lasting well over $1 \mathrm{~s}$ before returning to prestimulus rates (Fig. 1A). Relative to background rates, the mean amplitude and duration of efferent-mediated inhibition in $56 \mathrm{BT}$ afferents was $-32.0 \pm 1.9$ spikes/s and $1.72 \pm$ $0.11 \mathrm{~s}$, respectively. Delivery of the efferent shock train also inhibited BM afferents (Fig. $1 B$ ). Although the magnitude of the inhibition was comparable $(-28.6 \pm 1.2$ spikes $/ \mathrm{s}, n=76)$, the response in BM afferents differed from BT units in two distinct ways: (1) the inhibition was appreciably shorter $(0.413 \pm 0.012 \mathrm{~s})$ and (2) the inhibition was routinely followed by postinhibitory excitation (PIE) averaging an increase of $16.7 \pm 0.7$ spikes/s (Fig. $1 B$, arrowhead).

In contrast to responses of BT/BM afferents, efferent stimulation excited $\mathrm{CD}$ afferents (Fig. $1 C-F$ ). On average, the resting discharge in CD afferents was elevated by $45.8 \pm 1.6$ spikes/s and remained elevated for nearly $1 \mathrm{~s}(0.923 \pm 0.028 \mathrm{~s}, n=137)$. In most CD units, the excitatory response followed a simple decay back to baseline following termination of the efferent stimulus (Fig. 1C). However, in $\sim 15 \%$ (20 of 137) of the population, a small excitatory bump (Fig. $1 D$, asterisk) or a second excitatory peak (Fig. $1 E, F$ ) interrupted the decay trajectory. The presence of the second peak suggested that multiple efferent-mediated response components were present (Brichta and Goldberg, 2000b). There was also a correspondence in the timing of these secondary peaks in CD units with the peak of PIE seen in BM afferents (Fig. $1 B, D-F$, compare arrowheads). The similar timing suggested that these two excitatory phenomena might be attributed to the same efferent response mechanisms. Moreover, we specifically asked: might the presence of multiple efferent response mechanisms provide a basis for further discriminating calyx from dimorphic afferents? These observations provided the motivation for identifying the cellular and pharmacological mechanisms underlying each response in this study.

\section{Cholinergic efferent neurons synapse with afferents and type II hair cells}

In turtle cristae, VENs synapse on three targets: calyx-bearing afferents (i.e., calyx and dimorphic), type II hair cells, and bouton afferents innervating type II hair cells (Fig. 2A). The synaptic mechanisms underlying efferent-mediated inhibition of BT/BM afferents and excitation of CD afferents have been partially characterized (Holt et al., 2006b; Jordan et al., 2013). Efferentmediated inhibition of BT/BM afferents proceeds by way of activating $\alpha 9 \alpha 10 \mathrm{nAChRs}$ on type II hair cells whose calcium influx subsequently activates small-conductance, calciumdependent SKs to hyperpolarize the hair cell (Fig. 2A, right). This hyperpolarization inhibits the release of hair cell transmitter, presumably glutamate, onto the afferent, thereby inhibiting afferent discharge (Holt et al., 2006a,b). PIE in BM afferents also requires 
A

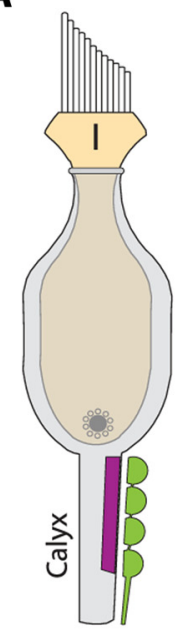

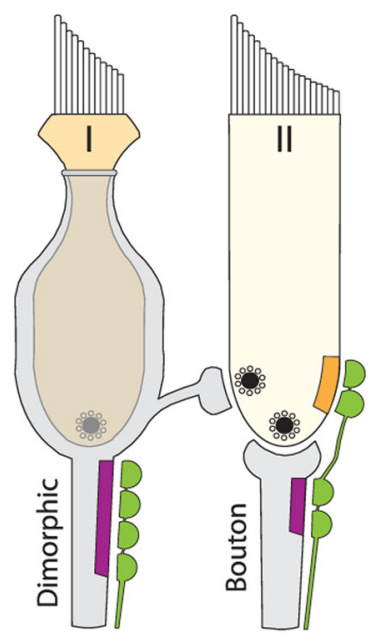

Efferent fiber and varicosities

$\alpha 9 \alpha 10$ nAChRs / SK

Afferent nAChRs $(\alpha 4 \beta 2, \alpha 9 \alpha 10$ ?)
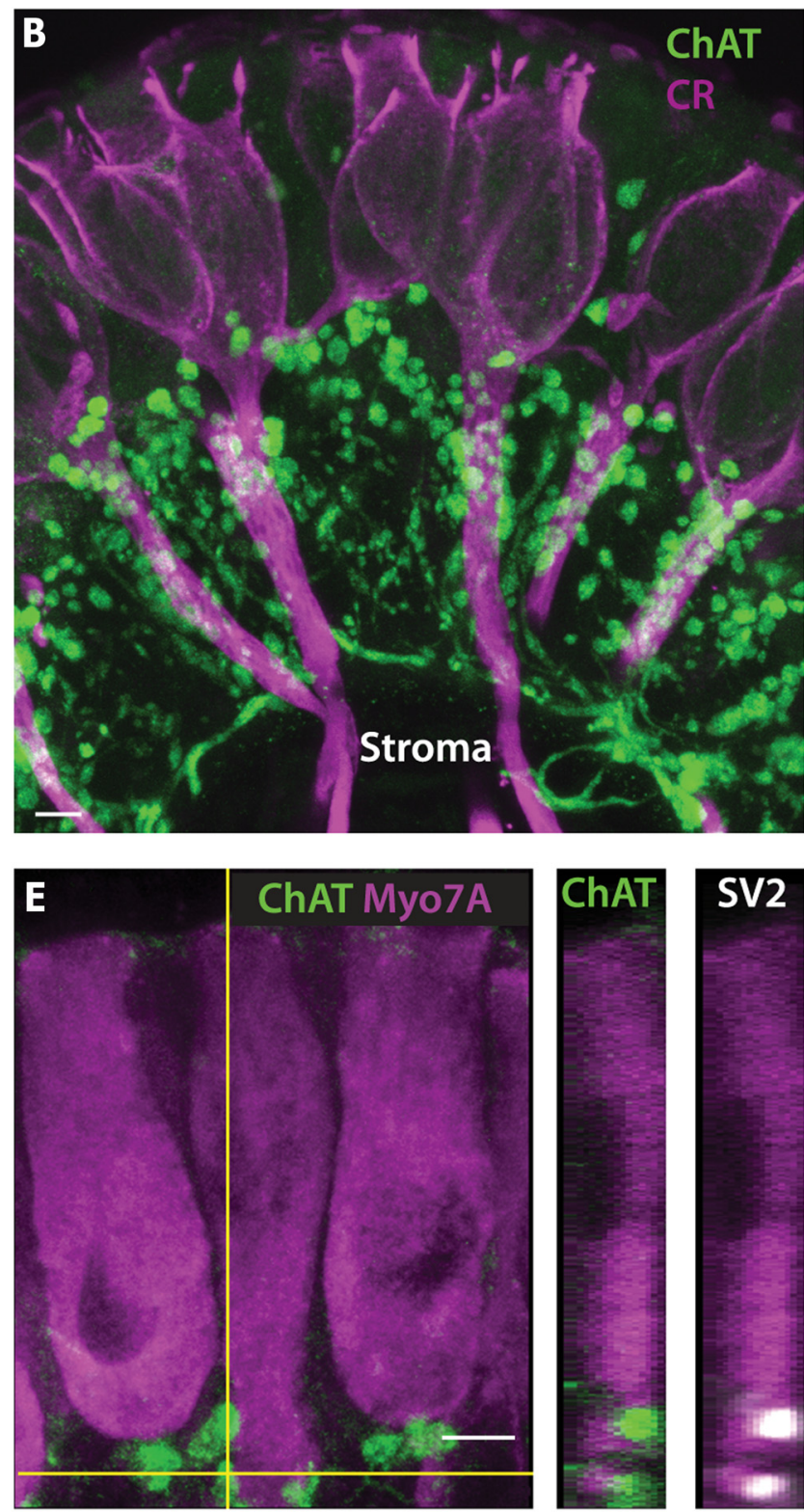

SV2
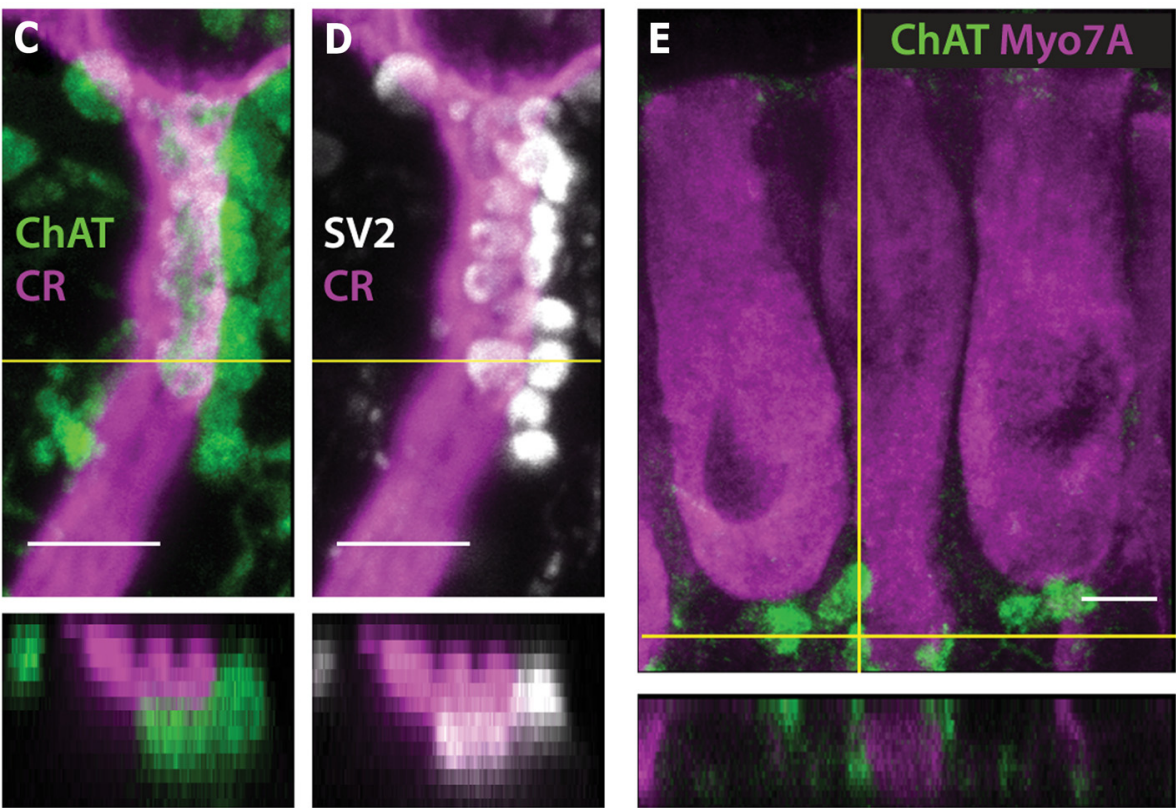

Figure 2. Efferent neurons innervate three distinct cellular targets in the turtle vestibular periphery. $\boldsymbol{A}$, Illustration depicting three cholinergic efferent synapses encountered in the turtle crista. Previous pharmacological data suggest the efferent postsynaptic complex in type II hair cells expresses $\alpha 9 \alpha 10 \mathrm{nAChRs}$ and SK channels whereas the postsynaptic complex on calyx, dimorphic, and bouton afferents may include $\alpha 4 \beta 2$ and $\alpha 9 \alpha 10 \mathrm{nAChRs.} \mathrm{I,} \mathrm{Type} \mathrm{I} \mathrm{hair} \mathrm{cells;} \mathrm{II,} \mathrm{type} \mathrm{II} \mathrm{hair} \mathrm{cells.} \boldsymbol{B}-\boldsymbol{E}$, Confocal image projections taken from transverse sections of turtle semicircular canal crista stained for ChAT (green), calretinin ( $\boldsymbol{B}-\boldsymbol{D},(\mathrm{CR}$, magenta), myosin VIIA ( $\boldsymbol{E}$, Myo7A, magenta), and SV2 ( $\boldsymbol{D}, \boldsymbol{E}$, white). $\boldsymbol{B}$, ChAT-positive efferent neurons profusely branch and populate the crista CZ with numerous spherical varicosities. $C$, ChAT-positive varicosities are clustered along the parent axon and base of a calyx-bearing afferent labeled by anti-calretinin. $\boldsymbol{D}$, Immunostaining for SV2 overlaps with ChAT-positive varicosities in the same tissue. $E$, ChAT-positive varicosities are concentrated along the base of type Il hair cells demarcated using antibodies against Myo7A. These ChAT-positive varicosities are also SV2-positive. To indicate proximity, orthogonal views (horizontal yellow lines) are presented at the bottom of $\boldsymbol{C}-\boldsymbol{E}$ and side views (vertical yellow line) are shown on the right side of $\boldsymbol{E}$. Orthogonal views in $\boldsymbol{C}$ and $\boldsymbol{D}$ reveal that only the front half of the calyx stalk was captured in the stack. Scale bars, $5 \mu \mathrm{m}$.

the activation of $\alpha 9 \alpha 10 \mathrm{nAChRs}$ and subsequent hyperpolarization of type II hair cells (Holt et al., 2006b). Efferent-mediated excitation of $\mathrm{CD}$ afferents is attributed to the activation of nAChRs that directly depolarize calyx and dimorphic afferents (Fig. 2A, left, middle). Existing pharmacological data suggested a role for $\alpha 4 \beta 2$ and $\alpha 9 \alpha 10 \mathrm{nAChRs}$ (Holt et al., 2006b; Jordan et al., 2013). Similar nAChRs are also found on BT/BM afferents, but inhibitory effects in type II hair cells typically mask their activation. Despite using similar efferent synaptic mecha- nisms, the responses of $\mathrm{BM}$ and dimorphic afferents to efferent stimulation are dominated by activation of nAChRs on the hair cell and afferent, respectively. Accordingly, we reasoned that the weight of the two efferent synaptic inputs might vary between the two afferent groups.

To assess how efferent synaptic structure varied among these targets, turtle semicircular canal cristae were processed immunohistochemically with antibodies to ChAT, calretinin, and myosin VIIA to label efferent fibers and varicosities, calyx-bearing affer- 
Table 2. Effects of cholinergic drugs on afferent responses to efferent stimulation

\begin{tabular}{|c|c|c|c|c|c|c|c|c|c|}
\hline \multirow[b]{2}{*}{ Drug $^{a}$} & \multirow{2}{*}{$\begin{array}{l}\text { Range of drug concentrations } \\
\text { used }(\mu \mathrm{M})\end{array}$} & \multicolumn{4}{|l|}{$C D$} & \multicolumn{4}{|c|}{$\mathrm{BT} / \mathrm{BM}$} \\
\hline & & $n$ & Control (spikes/s) ${ }^{b}$ & Drug (spikes/s) ${ }^{b}$ & $\%$ Block $^{c}$ & $n$ & 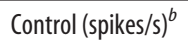 & Drug (spikes/s) ${ }^{b}$ & \%Block \\
\hline \multicolumn{10}{|c|}{$\alpha 9 \alpha 10$ nAChR antagonists } \\
\hline$\alpha \mathrm{BTX}$ & $1-3$ & 4 & $50.8 \pm 9.6^{*}$ & $45.2 \pm 10.6^{*}$ & 11 & 6 & $-26.1 \pm 3.7^{* *}$ & $0.6 \pm 1.6$ & $102^{* *}$ \\
\hline ICS & 10 & 11 & $39.3 \pm 4.8^{* *}$ & $27.3 \pm 4.0^{* *}$ & $31^{* *}$ & 16 & $-30.1 \pm 2.4^{* *}$ & $-1.0 \pm 1.5$ & $97^{* *}$ \\
\hline MLA & $0.1-3$ & 3 & $47.2 \pm 6.8^{*}$ & $5.0 \pm 1.6$ & $89^{*}$ & 11 & $-26.6 \pm 1.3^{* *}$ & $-1.1 \pm 0.8$ & $96^{* *}$ \\
\hline \multicolumn{10}{|c|}{ Afferent $n A C h R$ antagonists } \\
\hline DMPP & $5-20$ & 27 & $51.1 \pm 4.2^{* *}$ & $-5.6 \pm 2.3^{*}$ & $109^{* *}$ & 10 & $-22.1 \pm 5.4^{* *}$ & $-25.4 \pm 3.4^{* *}$ & -15 \\
\hline 5-iodo & $0.01-3$ & 4 & $62.8 \pm 19.7^{*}$ & $4.8 \pm 8.1$ & $92^{*}$ & 5 & $-36.1 \pm 7.0^{* *}$ & $-35.5 \pm 7.7^{* *}$ & 2 \\
\hline SazA & $0.01-3$ & 5 & $41.4 \pm 4.2^{* *}$ & $-2.6 \pm 2.8$ & $106^{* *}$ & 5 & $-36.1 \pm 4.3^{* *}$ & $-35.2 \pm 3.2^{* *}$ & 2 \\
\hline Varenicline & $0.1-1$ & 4 & $33.1 \pm 8.6^{*}$ & $3.9 \pm 3.4$ & $88^{*}$ & 5 & $-28.9 \pm 4.2^{* *}$ & $-29.5 \pm 3.6^{* *}$ & -2 \\
\hline
\end{tabular}

${ }^{a}$ Drug effects on average spike responses in CD and BT/BM afferents, taken from the first $100 \mathrm{~ms}$ interval immediately following the efferent shock train (20 shocks at 200/s). Drugs were classified as either $\alpha 9 \alpha 10$ or afferent nAChR antagonists.

${ }^{b}$ Mean discharge rate during shock train minus unstimulated background rate, before and after the indicated drug, respectively. Reported values are mean \pm SEM in the absence (Control) and presence (Drug) of identified cholinergic agent. A one-sample $t$ test was used to evaluate whether these means differed from zero; level of significance indicated by asterisk.

${ }^{c} 100 *$ ( 1 - Drug/Control) where: $0-100 \%$, drug response is smaller but of same sign as control response; $>100 \%$, drug response of opposite sign from control response; $<0 \%$, drug response larger but of same sign as control; statistical tests for \%Block, paired $t$ test between Drug and Control. For all statistical tests, asterisks indicate level of significance: ${ }^{*} p<0.05 ;{ }^{* *} p<0.01$.

ents, and hair cells, respectively (Fig. $2 B-E$ ). Upon leaving the stroma, ChAT-positive VEN fibers branched extensively (Fig. $2 B$ ) to give rise to many spherical varicosities that were deposited along calyx-bearing afferents (Fig. $2 B, C$ ) and the base of type II hair cells near the torus (Fig. $2 E$ ). In many calyx-bearing afferents, a large number of ChAT-positive efferent varicosities concentrated along the first $50 \mu \mathrm{m}$ of the axonal stalk, often stacking up along one side (Fig. 2B,C). Colabeling with anti-ChAT and antibodies against synaptic vesicle protein 2 (SV2) indicated that these varicosities likely represented presynaptic release sites (Fig. $2 D$ ). Orthogonal views (dashed lines) confirmed that these varicosities were in direct apposition with the calyx stalk (Fig. 2C,D, bottom). In Figure $2 C$, there were $\sim 17$ varicosities, immunolabeled for both ChAT and SV2, sitting directly adjacent to the calyx fiber. On average, there were $11.5 \pm 1.4 \mathrm{ChAT} / \mathrm{SV} 2+$ varicosities per calyx stalk ( $n=15,3$ animals). Smaller numbers of efferent puncta were localized along the basal one-third of type II hair cells in the middle and torus regions (Fig. $2 E$ ), averaging $4.3 \pm 0.5$ varicosities per hair cell ( $n=15,3$ animals). Orthogonal and side views (dashed lines) demonstrated that the varicosities were adjacent to the hair cell (Fig. 2E, bottom, right). Efferent varicosities were also seen scattered along the terminal processes of bouton afferents (data not shown). Although efferent varicosities on bouton afferent processes were not as densely packed as those on the calyceal stalk, those varicosities were not counted because it was often difficult to determine whether adjacent efferent varicosities and afferent terminals represented a direct contact or merely a juxtaposition of efferent and afferent synapses upon the base of type II hair cells (Jordan et al., 2013). The dense efferent innervation of calyxbearing afferents provided one explanation as to how efferentmediated excitation in dimorphic afferents might obscure efferent actions in type II hair cells. However, determining whether the secondary excitatory peaks in CD units reflect efferent actions on type II hair cells requires that we effectively resolve one efferent response mechanism from the other.

\section{$\alpha 9 \alpha 10$ nAChRs are not involved in efferent-mediated excitation of $C D$ afferents}

The pharmacological basis for distinguishing the $\mathrm{AChRs}$ driving efferent-mediated inhibition in BT/BM afferents, from those underlying efferent-mediated excitation in CD afferents, has pri- marily relied on intracellular recordings and differential blockade by the nAChR antagonists ICS and DH $\beta \mathrm{E}$ (Holt et al., 2006b). The utility of intracellular recordings is that we can simultaneously monitor the effects of efferent stimulation on the afferent's voltage and hair cell transmitter release by analyzing ensemble means and variances, respectively. Ensemble variance measurements, taken from high-pass-filtered records, provide an assessment of transmitter release from hair cells (Holt et al., 2006a,b, 2007). ICS, a potent antagonist of $\alpha 9 \alpha 10 \mathrm{nAChRs,} \mathrm{completely}$ blocked efferent-mediated inhibition in BT/BM afferents (Table 2 ), as well as the underlying voltage and variance changes attributed to inhibiting transmitter release from type II hair cells (Fig. $3 A$ ). Under control conditions, the efferent stimulus hyperpolarized the BT afferent and that hyperpolarization was associated with a concomitant decrease in the ensemble variance. The application of $10 \mu \mathrm{M}$ ICS blocked both the hyperpolarization and variance decrease. In seven BT/BM units, ICS blocked 93\% of the efferent-mediated variance decrease, suggesting that $\alpha 9 \alpha 10$ $\mathrm{nAChRs}$ are solely responsible for dialing back transmitter release. The variance decrease was consistent with a variation in qrate, as a log-log regression of ensemble skew versus the corrected ensemble variance for each of the seven units gave a mean slope of $1.04 \pm 0.01$.

The synaptic mechanisms governing efferent-mediated excitation of $\mathrm{CD}$ afferents can be contrasted with those in BT/BM afferents (Fig. 3B). During control conditions, the standard efferent stimulus depolarized the $\mathrm{CD}$ afferent a little over $1.5 \mathrm{mV}$. This depolarization, however, was not associated with a change in the variance that was shown earlier to depend on transmitter release from the hair cell (Holt et al., 2006a,b). Unlike efferent-mediated inhibition of BT/BM afferents, ICS only blocked $~ 30 \%$ of efferentmediated excitation (Table 2) and the underlying depolarization in $\mathrm{CD}$ afferents (Holt et al., 2006b). $\mathrm{DH} \beta \mathrm{E}$, at concentrations that do not antagonize $\alpha 9 \alpha 10$ nAChRs nor efferent-mediated inhibition in BT/BM afferents, inhibited $\sim 70 \%$ of the efferent-mediated depolarization in $\mathrm{CD}$ afferents (Fig. $3 B$ ). The complementary block of efferent-mediated excitation in CD afferents by ICS and DH $\beta$ E suggested that several nAChR subtypes, including $\alpha 9 \alpha 10$, were involved (Holt et al., 2006b).

To answer whether efferent-mediated excitation of CD afferents actually uses $\alpha 9 \alpha 10 \mathrm{nAChRs}$, we first applied $300 \mathrm{~nm} \mathrm{DH} \beta \mathrm{E}$ and then followed it with the coapplication of $300 \mathrm{nM} \mathrm{DH} \beta \mathrm{E}$ and 
$10 \mu \mathrm{M}$ ICS (Fig. 3B). The addition of 10 $\mu \mathrm{M}$ ICS, however, failed to block the depolarization remaining after $\mathrm{DH} \beta \mathrm{E}$ alone (Fig. 3B). In fact, the mean depolarization of six CD units, during the first $80 \mathrm{~ms}$ interval taken $20 \mathrm{~ms}$ after the efferent shock train, in the presence of $\mathrm{DH} \beta \mathrm{E}$ alone was not statistically significant from the corresponding mean depolarization acquired in the presence of $\mathrm{DH} \beta \mathrm{E}$ and ICS $(0.274 \pm 0.032 \mathrm{mV}$ vs $0.242 \pm 0.036 \mathrm{mV})$. These observations were inconsistent with a role for $\alpha 9 \alpha 10 \mathrm{nAChRs}$, and instead suggested that efferent-mediated excitation of CD afferents simply used nAChRs with sensitivity to both $\mathrm{DH} \beta \mathrm{E}$ and ICS. Three further pharmacological observations supporting this assertion are presented in the next section.

\section{The nicotinic agonist DMPP selectively blocks efferent-mediated excitation of CD afferents}

To further pharmacologically define the nAChRs underlying efferent-mediated excitation in turtle CD afferents, we used the nAChR agonist DMPP. DMPP was previously shown to selectively activate excitatory nAChRs, but not $\alpha 9 \alpha 10 \mathrm{nAChRs}$, in the frog vestibular system (Bernard et al., 1985; Holt et al., 2003). We reasoned that DMPP might work similarly in the turtle to aid in describing the excitatory nAChRs on CD afferents. We superfused low concentrations of DMPP (5-20 $\mu \mathrm{M})$ while recording the effects of the standard efferent stimulus on the resting discharge of CD afferents (Fig. 4A,B). During control conditions (superfusion of control solution), the standard efferent stimulus rapidly and repeatedly excited the CD afferent by almost 60 spikes/s. Each excitatory transient in the rate histogram represents the repeated presentation of single shock trains (Fig. 4A, Control). At $65 \mathrm{~s}$ (dashed line), we switched to control solution containing $20 \mu \mathrm{M}$ DMPP that, after a brief lag of $30 \mathrm{~s}$, slowly excited the afferent. DMPP-mediated excitation peaked $\sim 50 \mathrm{~s}$ into the application and then slowly decayed to background levels over several minutes despite continued DMPP delivery. Application of DMPP also abolished ongoing efferent-mediated excitation, suggesting that the same nAChRs contributed to both forms of excitation (Fig. 4A,B; Table 2). Upon washout, efferentmediated excitation returned to near-control levels (Fig. 4B).

The most likely explanation for the loss of efferent-mediated excitation during DMPP application is that DMPP first excited the afferent by activating the same nAChRs recruited during efferent stimulation. During continuous exposure, however, DMPP presumably desensitizes these $\mathrm{nAChRs}$, disabling any further activation by DMPP or ACh released from efferents during electrical stimulation. This phenomenon effectively allowed us to use DMPP as an antagonist, and it is the blockade by DMPP that is characterized in Figure $4 B$ and Table 2.

The concentrations of DMPP used here should have little effect on efferent-mediated inhibition, as DMPP is a poor agonist of $\alpha 9 \alpha 10$ nAChRs (Sugai et al., 1992; Guth et al., 1994; Elgoyhen et al., 2001; Sgard et al., 2002; Holt et al., 2003). Consistent with this prediction, the application of $20 \mu \mathrm{M}$ DMPP had no significant effect on efferent-mediated inhibition of afferent discharge in BT/BM units (Fig. 4C; Table 2). The nicotinic agonist cytisine $(0.3-1 \mu \mathrm{M})$ also directly excited CD afferents and subsequently

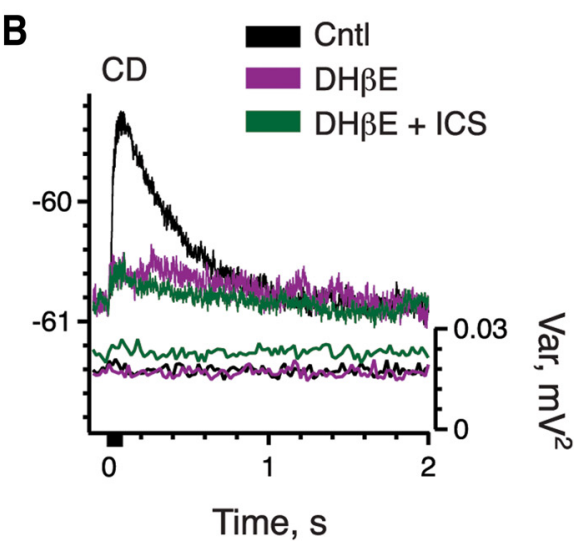

Time, s

Figure 3. Mechanisms of efferent-mediated inhibition are distinct from efferent-mediated excitation. $A, B$, Intracellular reshocks at 200/s, black bar at $t=0$ ) were delivered every $3-5$ s. Ensemble means (top, left axis in millivolts) and variances (bottom,

blocked efferent-mediated excitation while exhibiting little effect on efferent-mediated inhibition of BT/BM afferents (data not shown).

The effects of DMPP on efferent-mediated excitatory responses in CD units, and lack of effect on inhibition in BT/BM afferents, suggested that DMPP blocks nAChRs on the afferent while exerting little effect on the activation of $\alpha 9 \alpha 10 \mathrm{nAChRs}$ in type II hair cells. For further confirmation, we again turned to intracellular recordings to discriminate efferent effects on hair cells versus afferents. The application of $20 \mu \mathrm{M}$ DMPP blocked efferent-mediated depolarization in CD afferents (Fig. 4D). Neither the control depolarization nor the DMPPblocked response was associated with a change in the ensemble variance (Fig. 4D, bottom), indicating that the depolarization was not mediated by nAChRs on the hair cell. DMPP also selectively antagonized nAChRs on bouton afferents without interacting with $\alpha 9 \alpha 10 \mathrm{nAChRs}$ on type II hair cells (Fig. $4 E$ ). The initial depolarization (Fig. $4 E$, arrowhead) at the onset of efferent stimulation represents direct activation of $\mathrm{nAChRs}$ on the bouton afferent (Holt et al., 2006b). The application of DMPP blocked the initial depolarization and unmasked an efferent-mediated afferent hyperpolarization. This unmasking, however, took place without significant alterations in ensemble variance from the same time period. In four BT/BM units, the mean depolarization and variance decrease (expressed as percentage of baseline variance) was $0.190 \pm 0.181$ $\mathrm{mV}$ and $0.630 \pm 0.232 \mathrm{mV}^{2}$, respectively. After DMPP, the resulting hyperpolarization was $-1.840 \pm 0.452 \mathrm{mV}$ while the variance decrease was $0.910 \pm 0.026 \mathrm{mV}^{2}$. We concluded that DMPP antagonized excitatory nAChRs on turtle crista afferents without interacting with $\alpha 9 \alpha 10$ nAChRs on type II hair cells, thereby suggesting that $\alpha 9 \alpha 10 \mathrm{nAChRs}$ are not involved in efferent-mediated excitation.

\section{$\alpha$ BTX and $\alpha$-CtxRgIA do not antagonize efferent-mediated} excitation of $\mathrm{CD}$ afferents

The pharmacological evidence provided thus far argues that (1) nAChRs present on afferent processes are distinct from $\alpha 9 \alpha 10$ nAChRs on type II hair cells, and (2) $\alpha 9 \alpha 10$ nAChRs are not involved in efferent-mediated excitation. To further strengthen 
A

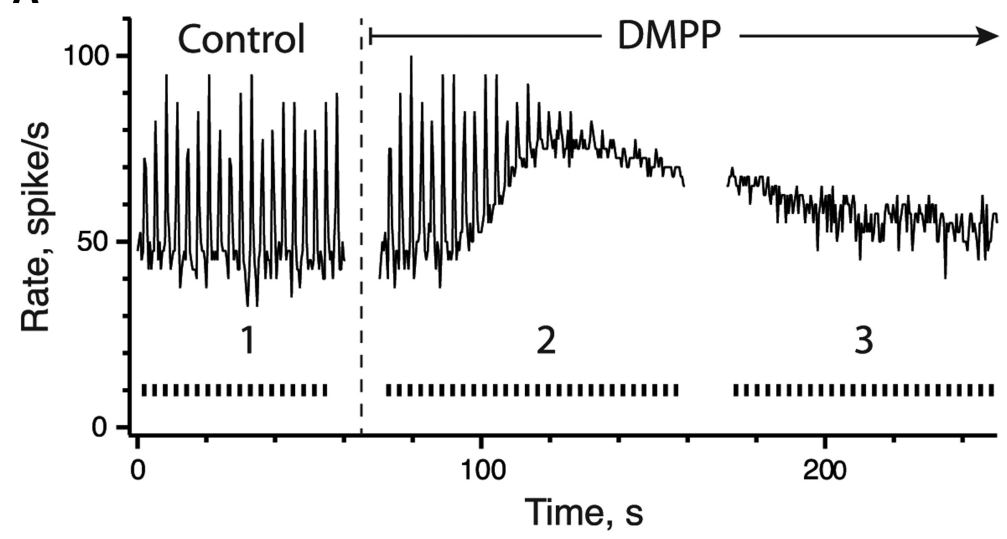

B

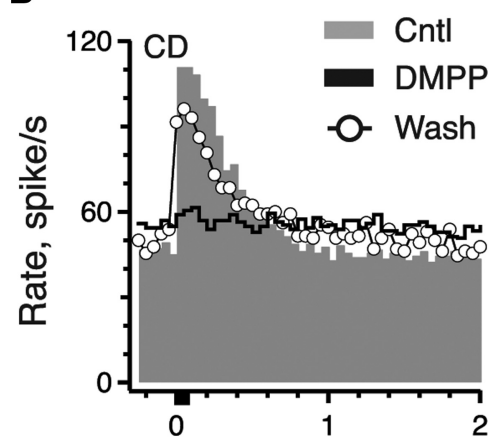

C

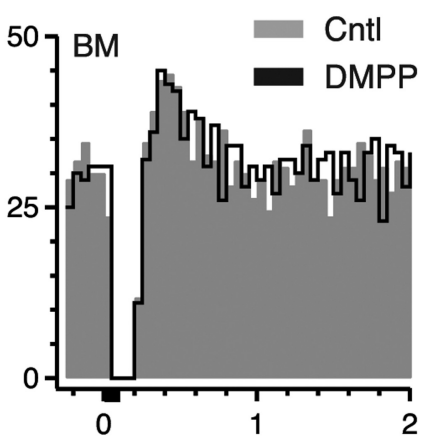

D

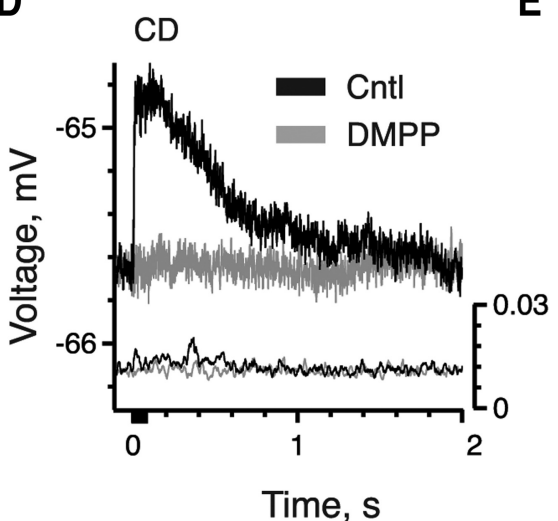

E

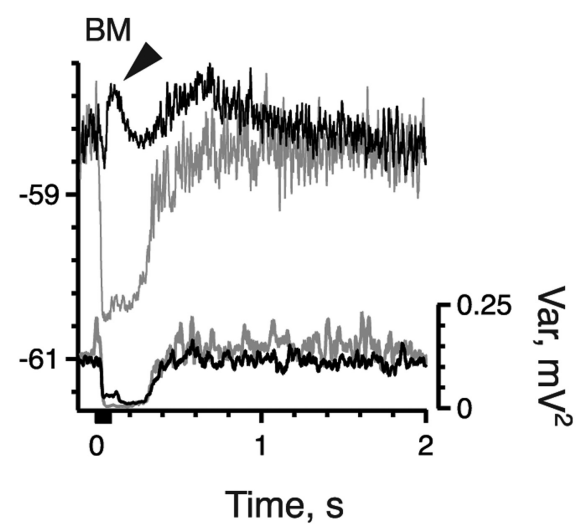

Figure 4. The nAChR agonist DMPP first mimics and then blocks efferent-mediated excitation in CD afferents. $\boldsymbol{A}$, The excitatory responses of a CD afferent to repeated efferent shock trains (black bars, bottom) are shown as a three-part rate histogram before (1) and during $(2,3)$ application of $20 \mu \mathrm{m}$ DMPP. Temporal gaps in graph represent $\sim 10$ s intervals between records. Control solution was superfused during control recordings and DMPP was started at $t=65 \mathrm{~s}$ (vertical dashed line) and remained on for the rest of the trace. $\boldsymbol{B}$, Corresponding average response histograms for control ( $\mathrm{Cntl}$ ) and DMPP were constructed from data shown in segments 1 and 3, respectively. The wash histogram was generated $15 \mathrm{~min}$ after returning to control solution (segment not shown). C, Average response histogram of a BM afferent to the standard efferent shock train before and during application of 20 $\mu$ M DMPP. D, E, Ensemble means (top, left axis in millivolts) and variances (bottom panel, right axis in square millivolts) were acquired from intracellular recordings of a CD and BM afferent in response to the standard efferent shock train before (black traces) and during application of $20 \mu \mathrm{M}$ DMPP (gray traces), respectively. Arrowhead in $\boldsymbol{E}$ indicates efferent-mediated depolarization presumably mediated by nAChRs on the afferent. In all panels, efferent shock trains ( 20 shocks at 200/s, black bars) were delivered every $3 \mathrm{~s}$. Ensemble means and variances as well as histograms were based on $\geq 19$ shock train presentations.

the argument, we used MLA, $\alpha \mathrm{BTX}$, and $\alpha$-CtxRgIA, three compounds that potently antagonize $\alpha 9 \alpha 10 \mathrm{nAChRs}$ in other hair cell systems (Fuchs and Murrow, 1992; Elgoyhen et al., 2001; Goutman et al., 2005; Ellison et al., 2006). Surprisingly, $1 \mu \mathrm{M}$ MLA potently blocked nearly $90 \%$ or greater of both efferent-mediated inhibition in BT/BM afferents and efferent-mediated excitation in CD afferents (Fig. $5 A, B$; Table 2). Lower concentrations of MLA $(0.1-0.3 \mu \mathrm{M})$ continue to completely block efferent-mediated inhibition in BT/BM afferents (Table 2), which is consistent with pharmacological observations with $\alpha 9 \alpha 10$ nAChRs (Verbitsky et al., 2000; Fucile et al., 2006). Although we did not conduct experiments with lower concentrations of MLA with efferent-mediated excitation in CD afferents, the magnitude and time course of block by $1 \mu \mathrm{M}$ MLA was similar between the two groups, suggesting overlapping sensitivities. These observations, while providing additional pharmacological information about afferent nAChRs, did not exclude a role for $\alpha 9 \alpha 10 \mathrm{nAChRs}$ in efferentmediated excitation of CD afferents. However, the remaining antagonists, $\alpha$ BTX and $\alpha$-CtxRgIA, were instructive in this regard. $\alpha$ BTX and $\alpha$-CtxRgIA blocked efferentmediated inhibition in BT/BM afferents (Fig. 5C,E; Table 2) while having little effect on efferent-mediated excitation in CD afferents (Fig. 5D, F; Table 2). The subsequent application of DMPP, however, blocked efferent-mediated excitation in the same $\mathrm{CD}$ units (Fig. 5D,F), indicating that the lack of effect with $\alpha$ BTX or $\alpha$-CtxRgIA was likely not related to issues with synaptic access. $\alpha$-CtxRgIA also exerted little effect on efferent-mediated excitation in bouton afferents as noted by the unmasking of an excitatory response in the $\mathrm{BM}$ unit after $\alpha$-CtxRgIA blockade (Fig. 5E). These data provide additional evidence that $\alpha 9 \alpha 10$ nAChRs do not play a role in efferentmediated excitation.

Pharmacology suggests a role for $\alpha 4$, $\alpha 6$, and $\beta 2 \mathrm{nAChR}$ subunits in efferentmediated excitation of $\mathrm{CD}$ afferents Selective $\alpha 4 \beta 2^{*} / \alpha 6 \beta 2^{*}$ agonists

The observation that efferent-mediated excitation of $\mathrm{CD}$ afferents is sensitive to low doses of $\mathrm{DH} \beta \mathrm{E}$ provided important insight into its potential $\mathrm{nAChR}$ subunit composition (Holt et al., 2006b; Table 1). As mentioned above, $70 \%$ of the efferentmediated excitation in $\mathrm{CD}$ units was blocked by $300 \mathrm{~nm} \mathrm{DH} \beta \mathrm{E}$ (Fig. $3 B$; Holt et al., 2006b), suggesting that $\mathrm{IC}_{50}$ estimates were even lower. If we limit our choices to nAChRs whose $\mathrm{IC}_{50}$ values for $\mathrm{DH} \beta \mathrm{E}$ are $<300 \mathrm{~nm}$, the list of possible contributing nAChRs subunits narrows considerably. Remaining candidates include $\alpha 4 \beta 2^{*}$ and $\alpha 4 \beta 4^{\star}$ (both non- $\alpha 6$ ), $\alpha 6 \beta 2^{\star}$, as well as $\alpha 7 \beta 2$ where the asterisks indicate the possible inclusion of other subunits (Table 1). We can likely rule out $\alpha 7 \beta 2 \mathrm{nAChRs} \mathrm{since}$ efferent-mediated excitation in $\mathrm{CD}$ afferents was not potently blocked by strychnine (Holt et al., 2006b) or $\alpha$ BTX (Fig. 5D; Table 2). Potent blockade of efferent-mediated excitation in $\mathrm{CD}$ afferents 

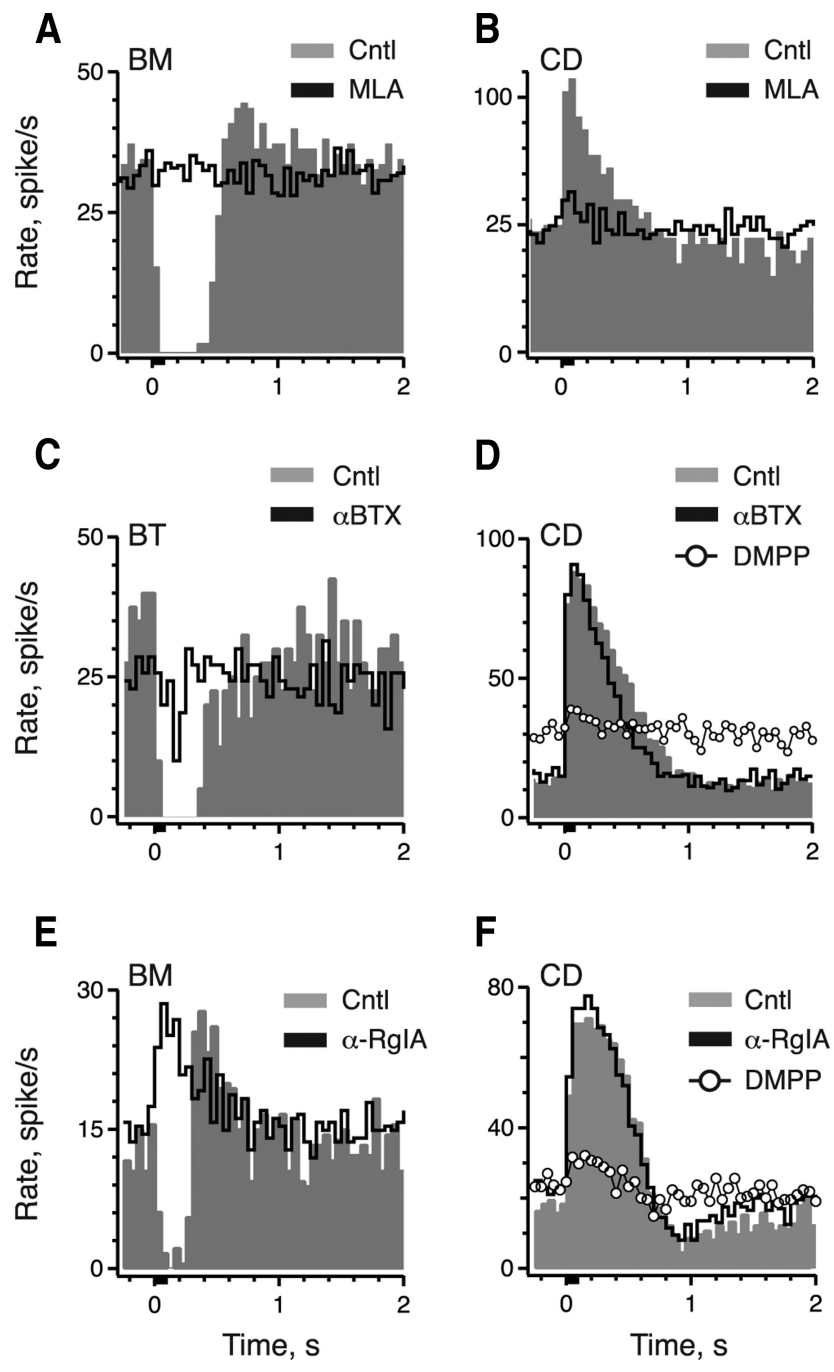
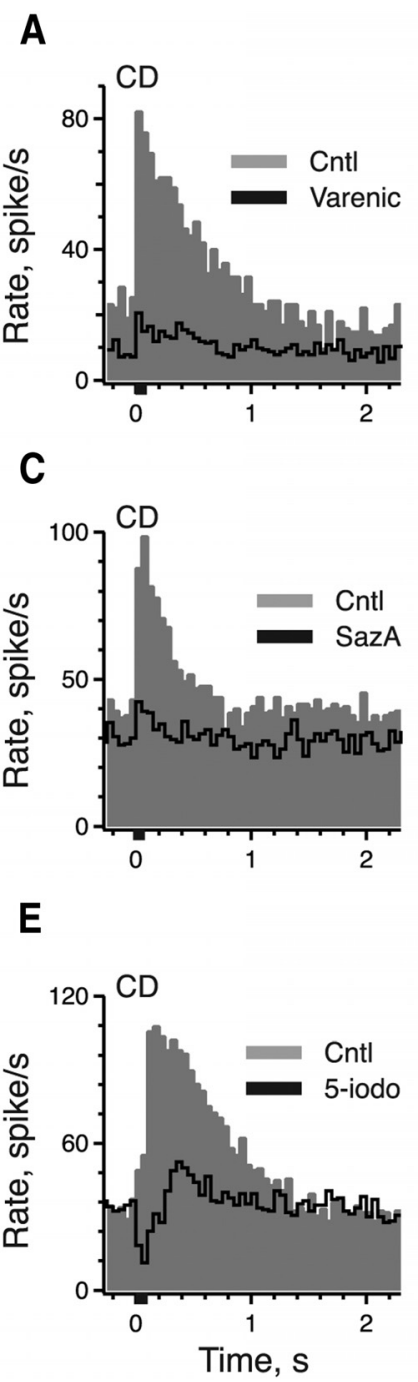

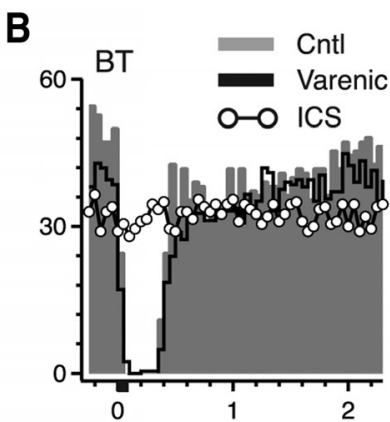

D

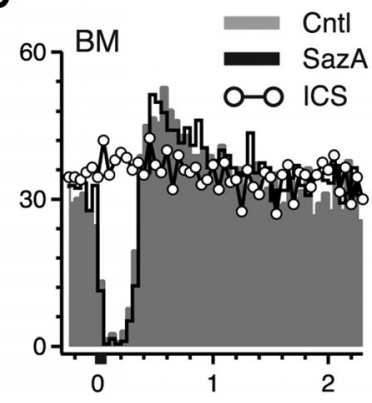

$\mathbf{F}$

Figure 5. Efferent-mediated activation of excitatory $n A C h R s$ on $C D$ afferents does not require $\alpha 9 \alpha 10 \mathrm{nAChRs} . \boldsymbol{A}, \boldsymbol{B}$, Average response histogram of a BM and $\mathrm{CD}$ afferent to the standard efferent shock train before and during application of $1 \mu \mathrm{MMLA}$, respectively. $C$, Average response histogram of a BT afferent to the standard efferent shock train before and during application of $1 \mu \mathrm{m} \alpha \mathrm{BTX}$. D, Average response histogram of a $\mathrm{CD}$ afferent to the standard efferent shock train before and during the serial application of $3 \mu \mathrm{m} \alpha \mathrm{BTX}$ and $20 \mu \mathrm{m}$ DMPP.E, Average response histogram of a $B M$ afferent to the standard efferent shock train before and during application of $333 \mathrm{~nm} \alpha$-CtxRgIA. $\boldsymbol{F}$, Average response histogram of a CD afferent to the standard efferent shock train before and during serial application of $667 \mathrm{~nm} \alpha$-CtxRgIA and $5 \mu \mathrm{M}$ DMPP. Efferent shock trains (20 shocks at 200/s, black bar at $t=0$ ) were repeated every $3 \mathrm{~s}$ and all histograms were based on $\geq 19$ shock train presentations.

by MLA (Fig. $5 B$ ) likely excludes $\alpha 4 \beta 4^{*}$ nAChRs (Evans et al., 2003), but would remain consistent with the pharmacology of both $\alpha 4 \beta 2^{*}$ and $\alpha 6 \beta 2^{\star}$ nAChRs (Mogg et al., 2002; Capelli et al., 2011).

To further discriminate between remaining receptor candidates, we applied several cholinergic compounds with selectivity toward $\alpha 4 \beta 2^{\star}$ and/or $\alpha 6 \beta 2^{\star}$ nAChRs. These included the three selective agonists varenicline, SazA, and 5-iodo, as well as two antagonists, $\alpha$-CtxMII and bPiDDB (Table 1). We first discuss the three agonists. Given our success achieving afferent nAChR blockade with the nonselective nAChR agonists DMPP and cytisine, we reasoned that the subtype-selective agonists (varenicline, SazA, and 5-iodo) might work in a similar fashion. That is, they might first selectively activate $\mathrm{DH} \beta \mathrm{E}$-sensitive nAChRs on calyx afferents and then, through competitive binding or subsequent desensitization of the receptors, block ongoing efferent-

Figure 6. Continuous application of selective $\alpha 4 \beta 2^{*} / \alpha 6 \beta 2^{*}$ nAChRs agonists selectively block efferent-mediated excitation of $C D$ afferents while having little effect on $\alpha 9 \alpha 10 \mathrm{nAChR}$ mediated inhibition of bouton afferents. $A, C, E$, Average response histograms of $C D$ afferents to the standard efferent shock train before and during application of $300 \mathrm{~nm}$ varenicline, $30 \mathrm{~nm}$ SazA, and $300 \mathrm{~nm} 5$-iodo, respectively. $\boldsymbol{B}, \boldsymbol{D}, \boldsymbol{F}$, Average response histograms of $B T / B M$ afferents to the standard efferent shock train before and during application of $300 \mathrm{~nm}$ varenicline, $30 \mathrm{~nm}$ SazA, and $300 \mathrm{~nm} 5$-iodo, respectively. Each series was then followed by the application of 10 $\mu \mathrm{m}$ ICS. Efferent shock trains ( 20 shocks at $200 / \mathrm{s}$, black bar at $t=0$ ) were repeated every $3 \mathrm{~s}$ and all histograms were based on $\geq 19$ shock train presentations.

mediated excitation in CD afferents. Unlike our observations with DMPP and cytisine, we did not observe upon the application of these three new agonists any consistent increase in the discharge rate of CD afferents. But varenicline, SazA, and 5-iodo, all at nanomolar concentrations, did block most of the efferentmediated increases in afferent discharge (Fig. 6A, C,E; Table 2) while exerting little effect on efferent-mediated inhibition in BT/BM afferents (Fig. 6B,D,F; Table 2). Presumably, these compounds had reasonable access to $\alpha 9 \alpha 10 \mathrm{nAChRs}$ on type II hair cells as subsequent application of ICS completely antagonized the inhibition in the same bouton afferents previously unaffected by prior exposures to varenicline, SazA, and 5-iodo. In some extracellular recordings from $\mathrm{CD}$ afferents, pharmacological blockade of efferent-mediated excitation unmasked an efferent-mediated inhibitory-excitatory response (Fig. 6E). The remaining biphasic response was remarkably similar to the typical efferent-mediated 
A

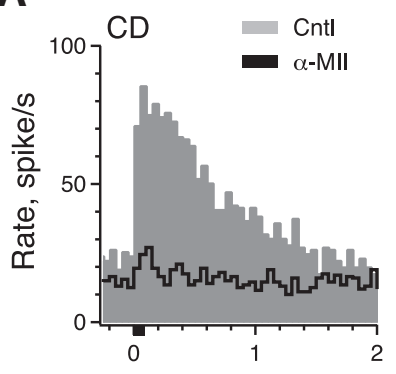

B

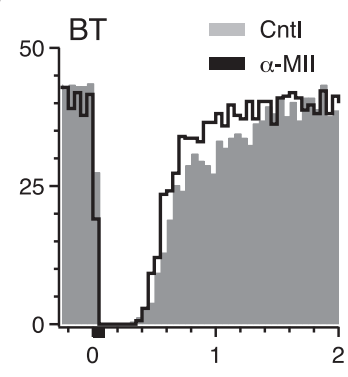

C

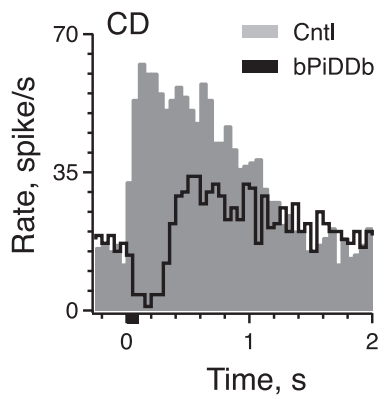

D

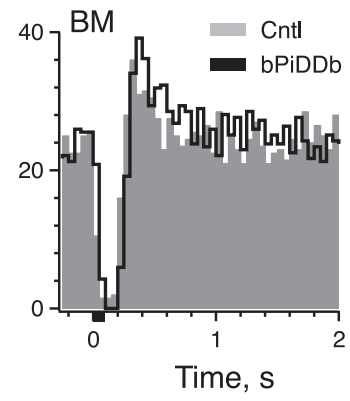

Figure 7. Pharmacology implicates $\alpha 6^{*} \mathrm{nAChRs}$ in efferent-mediated excitation of CD afferents. $\boldsymbol{A}, \boldsymbol{B}$, Average response histogram of a $C D$ and $B T$ afferent to the standard efferent shock train before and during the application of $2 \mu \mathrm{m} \alpha$-CtxMII, respectively. $C$, $D$, Average response histogram of a CD and BM afferent to the standard efferent shock train before and during application of $300 \mathrm{~nm}$ bPiDDB, respectively. Efferent shock trains ( 20 shocks at 200/s, black bar at $t=0$ ) were repeated every $3 \mathrm{~s}$ and all histograms were based on $\geq 20$ shock train presentations.

response seen in $\mathrm{BM}$ afferents (Figs. $1 B, 4 C$ ), particularly since both were unaffected by blockers of efferent-mediated excitation. The sensitivity to varenicline, SazA, and 5 -iodo further advocated a role for $\alpha 4 \beta 2^{\star}$ and/or $\alpha 6 \beta 2^{\star}$ nAChRs in efferent-mediated excitation.

\section{Selective $\alpha 6 \beta 2^{\star}$ antagonists}

The preceding pharmacological observations, along with the $\mathrm{DH} \beta \mathrm{E}$ sensitivity, suggested that $\alpha 4 \beta 2^{\star}$ and/or $\alpha 6 \beta 2^{*} \mathrm{nAChRs}$ are involved in efferent-mediated excitation of CD afferents. To further discriminate between these two receptor populations, we used two selective $\alpha 6^{\star}$-nAChR antagonists, $\alpha$-CtxMII and bPiDDB. $\alpha$-CtxMII is derived from the cone snail Conus magus, and has been shown to selectively block $\alpha 3 \beta 2^{*}$ and $\alpha 6 \beta 2^{*}$ nAChRs at low nanomolar concentrations (Cartier et al., 1996; McIntosh et al., 2004). The inclusion of $\alpha 3 \beta 2^{\star}$ nAChRs in our system, however, is unlikely given their micromolar sensitivity to DH $\beta E$ (Chavez-Noriega et al., 1997; Endo et al., 2005; Papke et al., 2008; but see Harvey and Luetje, 1996; Table 1). Nanomolar concentrations of $\alpha$-CtxMII failed to block efferent-mediated excitation in turtle CD afferents (data not shown), but we reliably saw blockade at higher concentrations. The application of 1-2 $\mu \mathrm{M} \alpha$-CtxMII blocked most of the efferent-mediated excitation in $\mathrm{CD}$ afferents without affecting efferent-mediated inhibition in BT/BM afferents (Fig. $7 A, B$; Table 2).

It can be argued, however, that the use of higher concentrations of $\alpha$-CtxMII would not distinguish $\alpha 6 \beta 2^{*}$ over $\alpha 4 \beta 2^{*}$ nAChRs (Cartier et al., 1996). To circumvent potential selectivity issues, we also used bPiDDB, a nonpeptide antagonist selective for $\alpha 6 \beta 2^{*}$ nAChRs (Smith et al., 2010; Table 1). Nanomolar concentrations of bPiDDB blocked efferent-mediated excitation in

CD afferents (Fig. 7C; Table 2), yet left efferent-mediated inhibition in BT/BM afferents intact (Fig. $7 D$; Table 2). Estimates of $\mathrm{IC}_{50}$ values were consistent with $\alpha 6 \beta 2^{*}$ nAChR blockade observed in the CNS (Table 1). Similar to observations with 5-iodo, blockade by bPiDDB also unmasked an inhibitory-excitatory response (compare Figs. $6 E, 7 C$ ). Together, the data presented in Figures 6 and 7 imply that activation of $\alpha 6 \beta 2^{\star}$ nAChRs underlies efferent-mediated excitation in CD afferents.

\section{Distinguishing calyx from dimorphic afferents in intracellular recordings}

We have shown that a number of cholinergic compounds selectively block efferent-mediated excitation in CD afferents without affecting efferent-mediated inhibition in BT/BM afferents. These observations also suggested that the remaining efferent-mediated inhibitory responses, seen in CD afferents following the administration of these compounds (Figs. $6 E, 7 C$ ), represent the unchallenged activation of $\alpha 9 \alpha 10 \mathrm{nAChRs}$ on type II hair cells innervating the same CD afferent. It also follows that CD afferents with such postblockade signatures were likely dimorphic. These inferences, however, are derived from extracellular recordings that predict what net voltages the spike encoder sees but provide little insight into the origin of each efferent-mediated component. For further clarification, we made measurements of ensemble voltage and variance in intracellular recordings from CD units during efferent stimulation and the application of cholinergic compounds that selectively blocked nAChRs on the afferent. We used the large efferent-mediated depolarization following the standard efferent-shock train to distinguish $\mathrm{CD}$ afferents from BT/BM afferents (Fig. 3). In 79 CD units, the mean depolarization during the $80 \mathrm{~ms}$ interval taken $20 \mathrm{~ms}$ after the efferent shock train was $0.92 \pm 0.05 \mathrm{mV}$. This is comparable to previously reported values and can be contrasted with hyperpolarizing values seen in $\mathrm{BT} / \mathrm{BM}$ afferents during the same time period (Holt et al., 2006b; Table 3).

In intracellular recordings during efferent-mediated excitation of CD afferents, we encountered one of three effects on ensemble variance: no change in variance, a variance decrease, or a variance increase. Mean ensemble voltage and variance data are provided in Table 3 for representative BT/BM afferents and the three groups of CD afferents. For CD afferents, reported mean values were tabulated from units where afferent nAChR blockers attenuated $>70 \%$ of the efferent-mediated depolarization. In 35 of $79 \mathrm{CD}$ units, there was no change in the ensemble variance during efferent stimulation, reaffirming the finding that changes in hair cell transmitter release played little, if any, role in afferent voltage changes in this group of CD units (Fig. 3B). Within this same group, there remained no variance change during efferent stimulation following the addition of afferent nAChR blockers (Fig. 4D). We labeled this first group CD_C (Table 3), as these efferent-mediated responses would be consistent with the sole activation of afferent nAChRs on calyx afferents (Fig. 2A).

In the second CD group (14 of 79), efferent-mediated depolarization was associated with a concomitant decrease in variance similar to the variance changes seen in BT/BM afferents (compare Figs. $4 E, 8 A$ ). Three further similarities may be noted: (1) selective blockade of afferent nAChRs subsequently unmasked a hyperpolarization without affecting the variance decrease (Fig. $8 A)$; (2) consistent with a change in qrate, a log-log regression of ensemble skew versus the corrected ensemble variance, after afferent nAChR blockade, yielded a mean slope of $1.03 \pm 0.02(n=$ 6 ); and (3) consistent with the activation of $\alpha 9 \alpha 10 \mathrm{nAChRs}$ on type II hair cells, subsequent application of ICS blocked the hy- 


\begin{tabular}{|c|c|c|c|c|c|c|c|c|}
\hline \multirow[b]{3}{*}{ Unit } & \multirow[b]{3}{*}{ Drug (concentration, $\mu \mathrm{M})^{b}$} & \multirow[b]{3}{*}{$n$} & \multicolumn{6}{|l|}{ Measure $^{a}$} \\
\hline & & & \multicolumn{3}{|l|}{ Voltage $(m V)^{c}$} & \multicolumn{3}{|l|}{ Variance $^{d}$} \\
\hline & & & Control $^{e}$ & Drug $^{e}$ & $\%$ Block $^{f}$ & Control $^{e}$ & Drug $^{e}$ & $\%$ Block $^{f}$ \\
\hline CD_C & $\alpha$-Ctxmll (2), bPiDDb (0.3), DH $\beta E(0.3-1), \operatorname{DMPP}(20), \operatorname{SazA}(0.01-0.3)$ & 14 & $0.83 \pm 0.08^{* *}$ & $0.13 \pm 0.02^{* *}$ & $84^{* *}$ & $-0.01 \pm 0.03$ & $-0.02 \pm 0.02$ & -81 \\
\hline$C D_{-} D$ & $\operatorname{DH} \beta E(0.1-1), \operatorname{DMPP}(20)$, siodo (0.03), SazA (0.1) & 9 & $1.16 \pm 0.28^{* *}$ & $-0.14 \pm 0.21$ & $112^{*}$ & $-0.27 \pm 0.08^{* *}$ & $-0.37 \pm 0.09^{* *}$ & -33 \\
\hline CD_E & bPiDDb (0.3), DH $\beta E(0.3-1)$, CYT (0.3), DMPP (5-20), 5iodo (0.3) & 10 & $0.95 \pm 0.12^{* *}$ & $0.17 \pm 0.03^{* *}$ & $83^{* *}$ & $0.41 \pm 0.10^{* *}$ & $-0.02 \pm 0.02$ & $104^{* *}$ \\
\hline
\end{tabular}

${ }^{a}$ Drug effects on ensemble mean and variance responses in CD and BT/BM afferents, from the first $80 \mathrm{~ms}$ interval taken $20 \mathrm{~ms}$ after the efferent shock train (20 shocks at 200/s).

${ }^{b}$ Specific drugs and concentrations used in each unit subclass.

'Average voltage during shock train minus background voltage.

${ }^{d}($ Var_eff/Var_back $)$ - 1, where Var_back and Var_eff are average ensemble variances before and during the train, respectively.

${ }^{e}$ Reported values for control and drug columns are means \pm SEM in the absence (Control) and presence (Drug) of drugs that selectively block afferent nAChRs. Mean values for CD entries were pooled from units where afferent nAChR antagonists blocked $>70 \%$ of the efferent-mediated depolarization. Mean values for BT/BM units were pooled from recordings under comparable pharmacological conditions, including concentrations and time of exposure. For each unit, ensemble measurements were tabulated from $10-25$ efferent shock presentations under both control and drug conditions. A one-sample $t$ test was used to evaluate if these means differed from zero; level of significance indicated by asterisk.

${ }^{f} 100$ * (1 - Drug/Control) where: $0-100 \%$, drug response smaller but of same sign as control response; $>100 \%$, drug response of opposite sign from control response; $<0 \%$, drug response larger but of same sign as control; statistical tests for \%Block, paired $t$ test between Drug and Control. For all statistical tests, asterisks indicate level of significance: ${ }^{*} p<0.05$; ${ }^{* *} p<0.01$.

perpolarization and variance decrease (Fig. $8 A ; n=4$ ). Since these similarities with $\mathrm{BM}$ afferents suggested that this group of $\mathrm{CD}$ afferents received type II hair cell input (Fig. 2E), we classified them as dimorphic (CD_D; Table 3).

In the last group of CD afferents (22 of 79), efferent-mediated depolarization was associated with a parallel variance increase (Fig. $8 B$ ). Because there was an efferent-mediated enhancement in the variance, we categorized the third group as CD_E. In contrast to efferent-mediated variance decreases in BT/BM and CD_D afferents, afferent nAChR blockers abolished the variance increase in CD_E afferents (Fig. 8B; Table 3). Unreliable estimates of residual variance in CD_E units obscured whether the efferent-mediated variance decrease was attributed to changes in qrate and/or qsize. Finally, five CD units showed a mixture of the variance changes seen in CD_D and CD_E units, while three other CD recordings showed no variance change under control conditions but variance decreases following afferent $\mathrm{nAChR}$ blockade (data not shown). These limited results suggest that in some CD units, synaptic mechanisms underlying each variance change coexist.

\section{Distinguishing calyx from dimorphic afferents in extracellular recordings}

To determine how the discharge of presumed dimorphic afferents differed from calyx afferents during efferent stimulation, we classified extracellular recordings from CD afferents as either calyx or dimorphic, based on the absence or presence of efferentmediated inhibition, respectively, in the overall efferent response (Fig. $9 A, B$ ). Here, we calculated the mean response histogram for each population before and after the application of nAChR antagonists (Fig. 9A, $B ; n=58,29$ each). We identified efferentmediated inhibition after either unmasking with afferent $n A C h R$ antagonists (Table 2, bottom; $n=46$ ) or as the fraction blocked by $\alpha 9 \alpha 10 \mathrm{nAChR}$ antagonists (Table 2, top, excluding MLA; $n=$ 12). Mean excitation in calyx afferents was significantly larger in amplitude and significantly shorter in duration than dimorphic
B

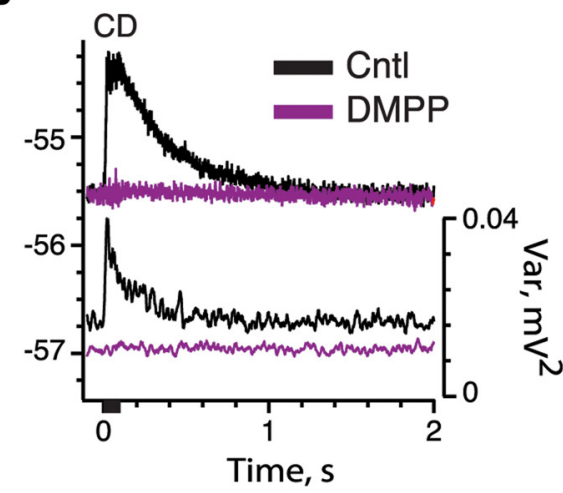

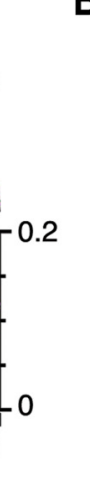

Time,
Cntl SazA

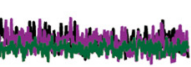

0.2

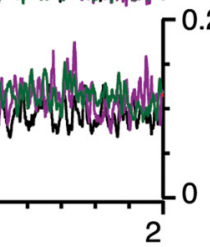

Time, $s$

Figure 8. Selective blockade of afferent $n A C h R s$ can be used to distinguish calyx from dimorphic afferents. Intracellular recordings were obtained from CD afferents during electrical activation of efferent fibers. Efferent shock trains ( 20 shocks at 200/s, black (b) were delivered every $3-5$ s. Ensemble means (top, left axis in millivolts) and variances (bottom, right axis in square genta), and then $10 \mu \mathrm{m}$ ICS (green). $\boldsymbol{B}$, Ensemble mean and variance in a CD afferent to the standard efferent shock train before (black) and during (magenta) application of $10 \mu \mathrm{m}$ DMPP.

afferents (Fig. 9A, B; Table 4), Mean prestimulus discharge rates were also significantly higher in dimorphic afferents.

To derive a nonpharmacological estimate of mean type II hair cell input, we subtracted the mean calyx population response from the mean dimorphic population response (Fig. $9 C$, solid line). This estimate is similar to mean inhibition-excitation in dimorphic afferents identified pharmacologically (Fig. 9B, C, dashed line). Differences in timing and amplitude are likely attributed to incomplete block of afferent nAChRs in the pharmacological setting and/or interactions between efferent response mechanisms lacking in the population estimate. Mean inhibition-excitation remaining in dimorphic afferents was nearly half of that seen in BM afferents (compare Figs. $1 B, 9 C$ ). This is likely a product of dimorphic afferents making fewer synapses with type II hair cells than BM afferents (Brichta and Peterson, 1994), and that synaptic input from type I hair cells is not inhibited during efferent stimulation.

The mean dimorphic response is interrupted along its falling edge by a small excitatory bump (Fig. 9B, asterisk). We previously hypothesized that this phenomenon might result from the activation of inhibitory-excitatory efferent mechanisms in type II hair cells (Fig. 1D-F). In further exploration, efferent-mediated 
A

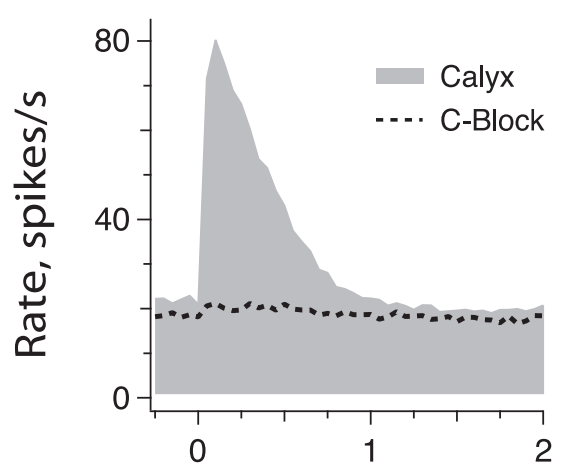

C

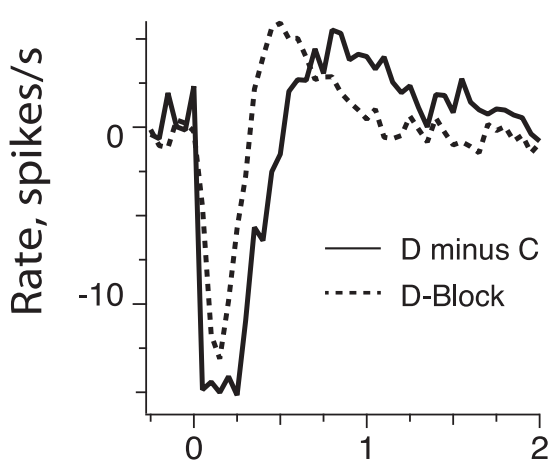

Time, $s$
B

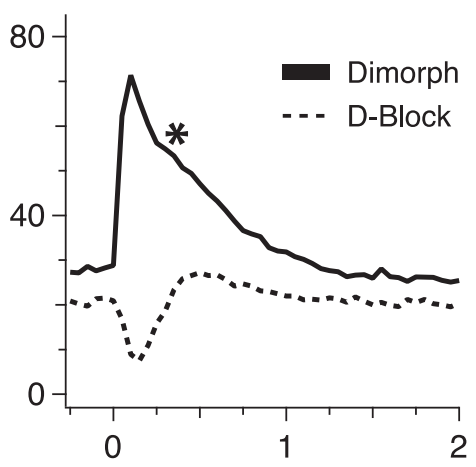

D

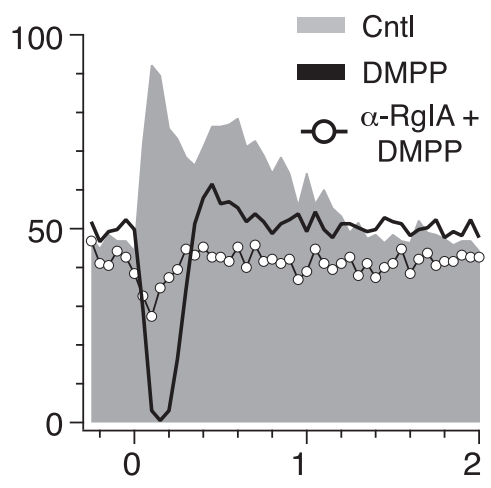

Time, $\mathrm{s}$

Figure 9. Multiphasic efferent-mediated excitatory responses in $C D$ units represent dimorphic afferents. $A, C D$ afferents where little to no efferent-mediated response remained following afferent nAChR blockade were classified as calyx-only afferents. An overall average response histogram from 29 such units that were averaged before (gray, Calyx) and after (dashed line, C-Block) $\mathrm{nAChR}$ blockade is shown. $\boldsymbol{B}, \mathrm{CD}$ afferents where mixed inhibitory-excitatory responses remained following afferent $\mathrm{nAChR}$ blockade were classified as dimorphic. The response histograms from 29 CD units met this criterion and were averaged before (solid line, Dimorph) and after (dashed line, D-Block) nAChR blockade. C, Mean difference between calyx and dimorphic afferents was estimated by subtracting the mean calyx response histogram from the mean dimorphic histogram (solid line, D minus C). This estimate is then compared with the histogram remaining after afferent $n A C h R$ blockade in dimorphic afferents (D-Block). D, Average response histograms of a presumed dimorphic afferent to a standard efferent shock train are shown before and during the serial application of $10 \mu \mathrm{m}$ DMPP and then $10 \mu \mathrm{m}$ DMPP with $667 \mathrm{~nm} \alpha$-CtxRgIA. Efferent shock trains (20 shocks at 200/s, black bar at $t=0$ ) were repeated every $3-5 \mathrm{~s}$ and histograms were based on $\geq 20$ shock train presentations.

excitation of the CD afferent in Figure $1 E$ was characterized during the application of DMPP $(20 \mu \mathrm{M})$ and $\alpha$-CtxRgIA (667 nM). DMPP abolished the efferent-mediated excitation and unmasked an inhibitory-excitatory response whose PIE would contribute to the second excitatory peak under control conditions (Fig. 9D). Under similar pharmacology, a clear association between PIE and the second excitatory control peak was identified in 14 CD afferents. That such remaining inhibitory-excitatory responses are mediated by $\alpha 9 \alpha 10 \mathrm{nAChRs}$ on type II hair cells is supported by a sensitivity to blockade by $\alpha$-CtxRgIA (Fig. $9 D$ ) and ICS (data not shown).

\section{Immunohistochemistry with $\mathrm{nAChR}$ antibodies}

The pharmacological observations with $\mathrm{DH} \beta \mathrm{E}, \alpha$-CtxMII, bPiDDB, and antagonists of $\alpha 9 \alpha 10$ nAChRs suggested that efferent-mediated excitation in CD afferents uses $\alpha 6 \beta 2^{*}$ as opposed to either $\alpha 4 \beta 2^{\star}$ (non- $\alpha 6$ ) or $\alpha 9 \alpha 10$ nAChRs. However, we won- dered whether $\alpha 4$ or $\alpha 9$ nAChR subunits might coassemble with $\alpha 6$ and $\beta 2$ in forming functional nAChRs on calyceal endings. There is convincing evidence for $\alpha 4 \alpha 6 \beta 2^{*}$ nAChRs on dopaminergic neurons of the ventral tegmental area (Champtiaux et al., 2003), and the inclusion of the $\alpha 9$ nAChR subunit would be consistent with previous IHC and $\alpha$-bungarotoxin data (Ishiyama et al., 1995; Wackym et al., 1995; Dailey et al., 2000; Luebke et al., 2005).

To gain further insight into the participation of $\alpha 9$ and $\alpha 4 \mathrm{nAChR}$ subunits in efferent-mediated excitation of turtle CD afferents, we probed turtle crista neuroepithelia and vestibular ganglia using IHC for $\alpha 9, \alpha 4$, and $\beta 2 \mathrm{nAChR}$ subunits. We sequenced the gene for the $\alpha 9$ nicotinic receptor subunit from turtle inner ear tissue and used this information to generate a polyclonal antibody, IL-308 (see Materials and Methods). As a test of specificity, we used IL-308 to probe Western blots of turtle inner ear tissue homogenates and obtained a $\sim 57 \mathrm{kDa}$ band (the appropriate size) for the turtle $\alpha 9 \mathrm{nAChR}$ subunit (Fig. 10A). Preincubation of IL-308 with excess peptide antigen blocked subsequent labeling. Confocal micrographs were generated from turtle posterior cristae stained with IL-308 and anti-calretinin (Fig. 10CE). Immunostaining for IL-308 was consistent with our pharmacological observations whereby type II hair cells (II) in the $\mathrm{PZ}$ near the torus were $\alpha 9$-positive, while presumed BT afferents (Fig. 10C, arrowhead) innervating them were calretininpositive and $\alpha 9$-negative. Staining patterns of calyx afferents in the CZ resembled bouton afferents in being calretinin-positive, but $\alpha 9$-negative (Fig. $10 D, E$, arrowheads). In the same section, type II hair cells in the adjacent $\mathrm{PZ}$ were both $\alpha 9$-positive and calretinin-positive (Fig. 10D,E, arrows). These data suggest that the $\alpha 9$ subunit does not contribute to direct efferent-mediated excitation of turtle vestibular afferents.

We also used two commercially available mammalian antibodies to map out the expression of $\alpha 4$ and $\beta 2 \mathrm{nAChR}$ subunits in turtle vestibular tissue (Fig. $10 F-I$ ). In these experiments, we observed staining for both $\alpha 4$ and $\beta 2 \mathrm{nAChR}$ subunits in turtle vestibular ganglia containing the cell bodies for primary vestibular afferents (Fig. $10 F, H$ ) as well as in the crista neuroepithelium (Fig. 10G,I). In the crista (Fig. 10G,I), staining from both antibodies was generally superimposable where they labeled bouton afferent fibers and terminals near the torus and planum (arrows), calyx-bearing afferents in the CZ (arrowheads), and type II hair cells near the planum (II). These observations are consistent with a role for both $\alpha 4$ and $\beta 2 \mathrm{nAChR}$ subunits in efferent-mediated excitation of vestibular afferents and suggest a possible role for $\alpha 4 \beta 2^{\star}$ nAChRs in planum type II hair cells. Preliminary IHC results for the commercial antibody we used against $\alpha 6$, however, were inconclusive (data not shown). 
Table 4. Comparison of efferent-mediated excitation in calyx versus dimorphic afferents

\begin{tabular}{|c|c|c|c|c|c|c|c|}
\hline Unit & $n$ & Normalized coefficient of variation ${ }^{a}$ & Background discharge (sp/s) $^{a}$ & Peak exitation $(\mathrm{sp} / \mathrm{s})^{b}$ & Mean T100 (sp/s) & Half-width $(\mathrm{s})^{d}$ & Duration $(s)^{e}$ \\
\hline Calyx $x^{f}$ & 29 & $0.7621 \pm 0.0267$ & $19.3 \pm 2.0^{*}$ & $61.8 \pm 4.4^{*}$ & $54.7 \pm 4.3^{*}$ & $0.383 \pm 0.023$ & $1.071 \pm 0.058^{*}$ \\
\hline Dimorphic $^{f}$ & 29 & $0.7061 \pm 0.0235$ & $25.7 \pm 2.3$ & $46.9 \pm 3.1$ & $40.1 \pm 2.9$ & $0.477 \pm 0.040$ & $1.376 \pm 0.071$ \\
\hline
\end{tabular}

${ }^{a}$ Normalized coefficient of variation and background discharge were calculated from $5 \mathrm{~s} \alpha$ period devoid of any efferent stimulus.

${ }^{b}$ Peak excitation was taken from the first $50 \mathrm{~ms}$ bin of the average response histogram.

'Mean efferent-mediated excitation during the first $100 \mathrm{~ms}$ interval immediately following the efferent shock train (20 shocks at 200/s).

${ }^{d}$ Time it took the response to return to half the peak excitation.

eTime it took the response to return to background.

${ }^{f_{S}}$ tatistical test for unit response properties, unpaired $t$ test for calyx versus dimorphic. For all statistical tests, asterisks indicate level of significance: ${ }^{*} p<0.05 ;{ }^{* *} p<0.01$.
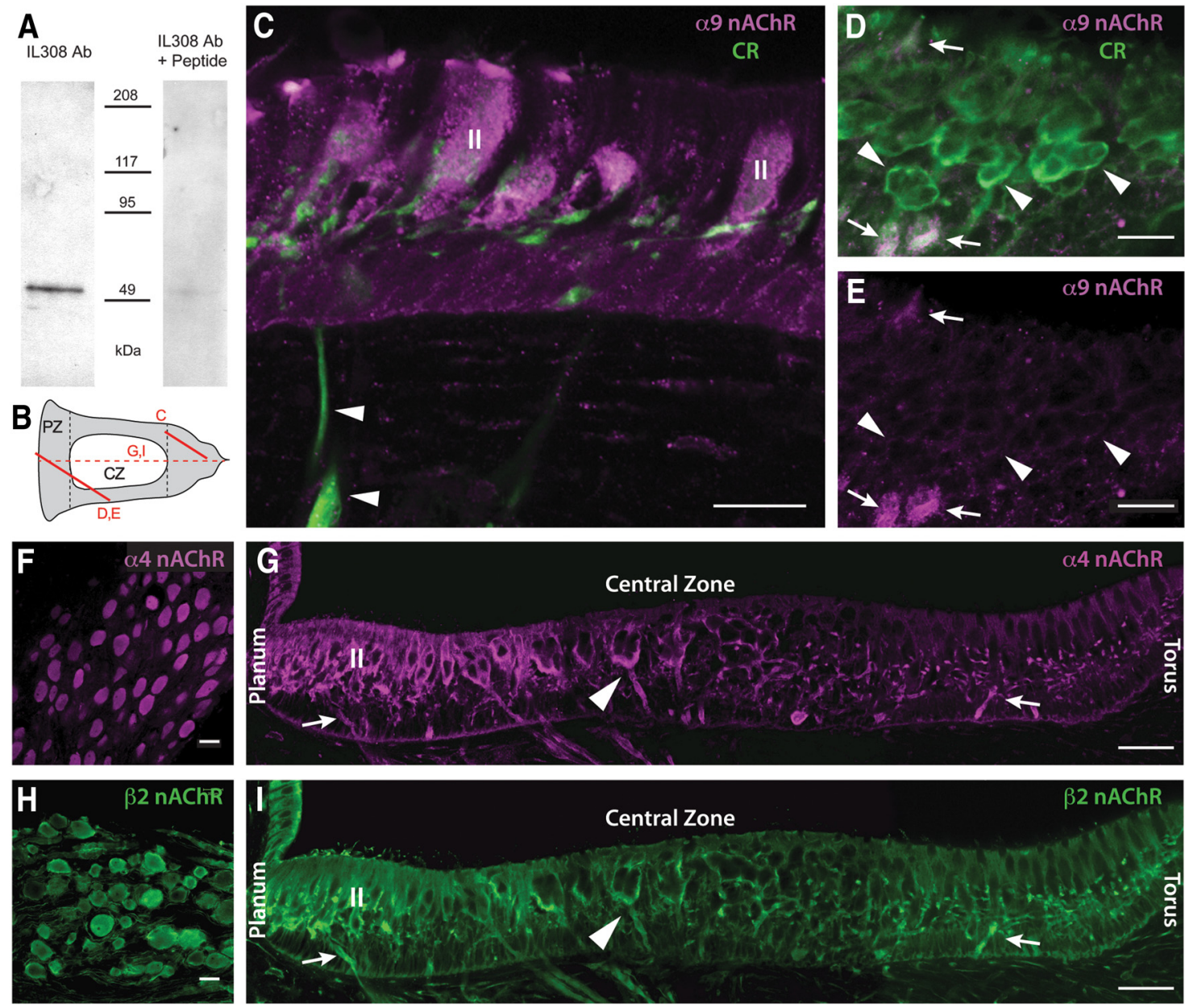

Figure 10. Immunohistochemistry for $\alpha 9, \alpha 4$, and $\beta 2 \mathrm{nAChR}$ subunits. A, Western blot with our IL-308 antibody shows that $\alpha 9 \mathrm{nAChR}$ subunit protein is present as a single band of the predicted molecular weight $(\approx 56 \mathrm{kDa})$ in turtle inner ear tissue. Preincubation with an excess of antigen peptide (IL $308 \mathrm{Ab}+$ peptide) blocked detection of the band. $\boldsymbol{B}$, Schematic of turtle hemicrista indicates the plane of sectioning for subsequent panels (Fig. 1, top). C, Antibodies to calretinin (CR) stained bouton afferent nerve fibers (green, arrowheads) innervating type II hair cells in the PZ near the torus. IL-308 stained torus type II hair cells (magenta, II), but not associated bouton endings (green). $\boldsymbol{D}, \boldsymbol{E}$, Section through the CZ and the adjacent PZ stained for CR and $\alpha 9 \mathrm{nAChR}$ subunit. Calyx fibers and endings in $C Z$ ( $\boldsymbol{D}$, green, arrowheads) are, at most, very lightly stained with the $\alpha 9$ antibody ( $\boldsymbol{E}$, magenta), while two typell hair cells in adjacent $\mathrm{PZ}(\boldsymbol{D}$, white; $\boldsymbol{E}$, magenta, arrows) are stained with both CRand the $\alpha 9$ antibodies. $\boldsymbol{F}, \boldsymbol{H}$, Antibodies to $\alpha 4 \mathrm{nAChR}$ subunits $(\boldsymbol{F})$ and $\beta 2 \mathrm{nAChR}$ subunits $(\boldsymbol{H})$ label cells in vestibular ganglia. $\boldsymbol{G}, \boldsymbol{I}$, Antibodies to $\alpha 4$ and $\beta 2 \mathrm{nAChR}$ subunits both label bouton afferents near the torus and planum (arrows), calyx-bearing afferents in the CZ (arrowheads), and type II hair cells (II) near the planum. Both panels are from the same crista section. Scale bars, $20 \mu \mathrm{m}$.

Expression of nAChR subunits in turtle vestibular tissue

Since the validity and specificity of many cholinergic receptor antibodies have been called into question (Moser et al., 2007; Jositsch et al., 2009), we sought additional experimental support to validate the expression of $\alpha 9, \alpha 4$, and $\beta 2$ in turtle vestibular tissue. We performed ISH using primers derived from the turtle $\alpha 9$ nAChR gene and the partial coding sequences of the turtle $\alpha 4$ and $\beta 2 \mathrm{nAChR}$ genes that we cloned (accession numbers AY768813, EU526107, EU526108). ISH revealed that $\alpha 9$ mRNA expression was primarily confined to the hair cell layer (Fig. 11A, inset) where the label was more intense near the torus and became less intense or absent when moving toward the planum regions (Fig. 11A). In agreement with the immunohistochemistry, ISH demonstrated that turtle vestibular ganglion cells expressed the mRNA for $\alpha 4$ and $\beta 2$ $\mathrm{nAChR}$ subunits (Fig. 11C,E). No label was present in ISH experiments using sense probes (Fig. $11 B, D, F$ ).

\section{Discussion}

The initial impetus for this work came from pharmacological differences in nAChRs governing efferent actions on hair cells 


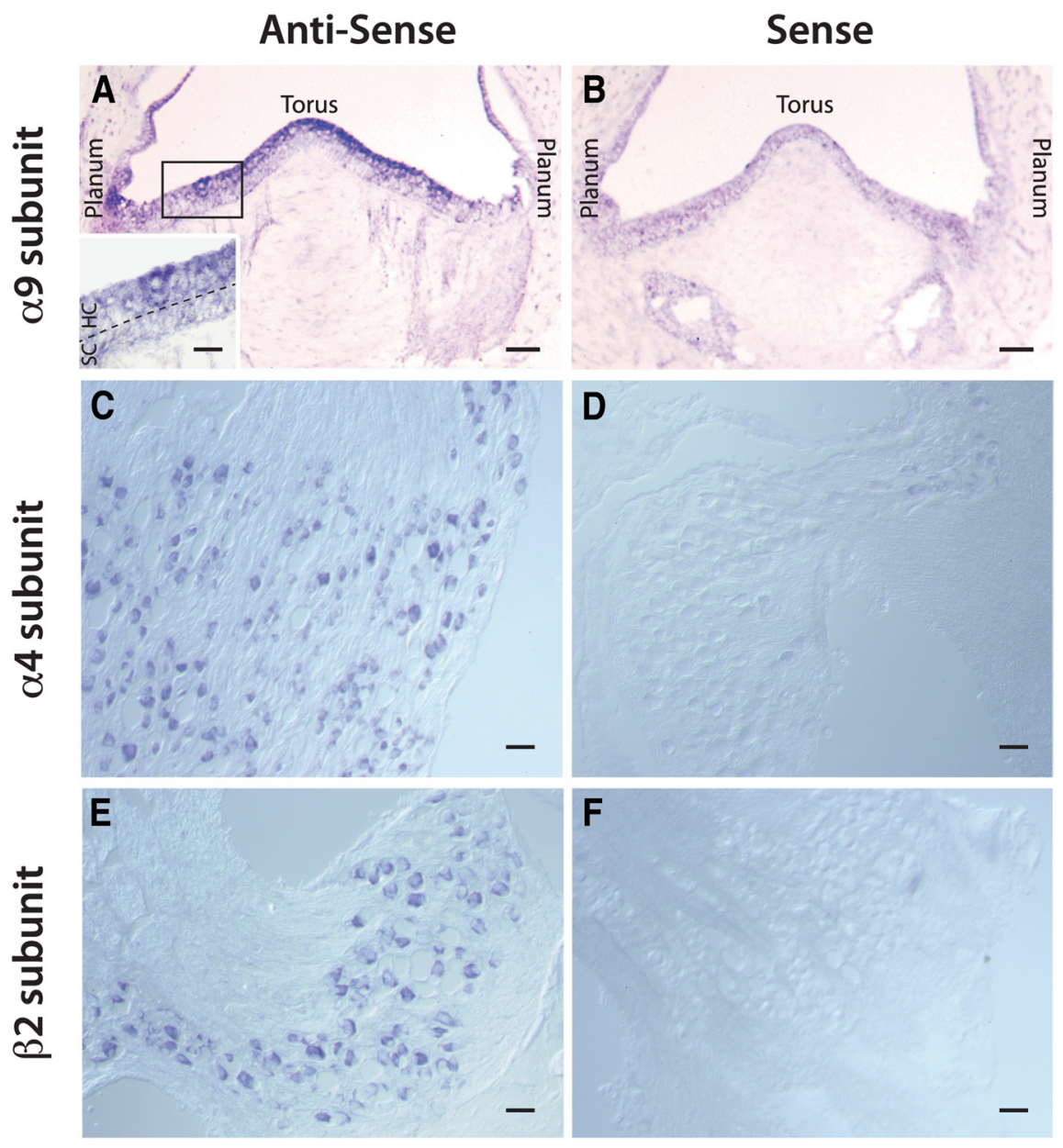

Figure 11. Expression of $\alpha 9, \alpha 4$, and $\beta 2 \mathrm{nAChR}$ subunit mRNA in turtle tissue. $\boldsymbol{A}, \boldsymbol{B}, \boldsymbol{C}, \boldsymbol{E}$, ISH using nAChR subunit-specific antisense probes in the turtle crista $(\boldsymbol{A}, \boldsymbol{B})$ and vestibular ganglia $(\boldsymbol{C}, \boldsymbol{E}) . \boldsymbol{A}$, In longitudinal sections of the posterior crista (Fig. 10B, diagram), $\alpha 9$ nAChR subunit mRNA was localized to the hair cell layer (HC) with more intense labeling near the torus. Inset, Higher-magnification image of labeled hair cells taken from box. Dashed line demarcates $\mathrm{HC}$ and supporting cell (SC) layers. $\boldsymbol{C}, \boldsymbol{E}$, Both $\alpha 4$ and $\beta 2 \mathrm{nAChR}$ subunit mRNA were found in vestibular ganglia, respectively. $\boldsymbol{B}, \boldsymbol{D}, \boldsymbol{F}$, Sense controls for each $\mathrm{nAChR}$ subunit showed no labeling. Scale bars: inset, $20 \mu \mathrm{m} ; \boldsymbol{A}, \boldsymbol{B}, 50 \mu \mathrm{m} ; \boldsymbol{C}-\boldsymbol{F}, 20 \mu \mathrm{m}$.

versus afferent processes in the turtle posterior crista (Holt et al., 2006b). In the previous study, efferent-mediated inhibition of bouton afferents was attributed to the activation of $\alpha 9 \alpha 10$ nAChRs on type II hair cells that was potently blocked by strychnine and ICS. In contrast, efferent-mediated excitation of CD afferents was attributed to the direct activation of nAChRs on calyceal endings that were partially blocked by $\mathrm{DH} \beta \mathrm{E}$, at concentrations having little effect on $\alpha 9 \alpha 10$ nAChRs. However, nAChRs on CD afferents were also partially blocked by ICS, suggesting that at least two distinct populations of nAChRs, including $\alpha 9 \alpha 10$, might play a role in efferent-mediated excitation.

In this study, we sought to further discriminate nAChRs that underlie efferent-mediated excitation of CD afferents. We anticipated additional pharmacology would provide insight into their subunit composition. Using a series of selective cholinergic compounds, four lines of evidence indicated that the pharmacology of nAChRs on CD afferents is consistent with the activation of $\alpha 6 \beta 2^{\star}$, but not $\alpha 9 \alpha 10$, nAChRs. First, coapplication of $\mathrm{DH} \beta \mathrm{E}$ and ICS failed to completely block efferent-mediated depolarization in CD afferents, suggesting that the block observed with $\mathrm{DH} \beta \mathrm{E}$ or ICS alone did not correspond to two distinct populations of nAChRs, but rather a single population with sensitivity to both $\mathrm{DH} \beta \mathrm{E}$ and ICS. Second, SazA, 5-iodo, varenicline, $\alpha$-CtxMII, and
bPiDDB potently antagonized efferentmediated excitation in $\mathrm{CD}$ afferents while exhibiting little effect on efferent-mediated inhibition in BT/BM afferents. Third, the $\alpha 9 \alpha 10$ nAChR antagonists, $\alpha$ BTX and $\alpha$-CtxRgIA, did not block efferent-mediated excitation in $\mathrm{CD}$ afferents while blocking efferent-mediated inhibition in BT/BM afferents. Finally, IHC and ISH data for the $\alpha 9$ $\mathrm{nAChR}$ subunit in turtle were consistent with the pharmacological findings.

\section{Insight into subunit composition of nAChRs on CD afferents}

Given that low concentrations of $\mathrm{DH} \beta \mathrm{E}$ antagonized efferent-mediated excitation in CD afferents (Holt et al., 2006b), it was initially proposed that activation of $\alpha 4 \beta 2$ nAChRs was responsible. This proposal was consistent with previous pharmacological characterization of $\alpha 4 \beta 2 \mathrm{nAChRs}$ (Harvey and Luetje, 1996; Chavez-Noriega et al., 1997; Iturriaga-Vásquez et al., 2010), as well as the expression of $\alpha 4$ and $\beta 2$ nAChR subunits in primary vestibular neurons (Wackym et al., 1995; Zoli et al., 1995; Hiel et al., 1996; Anderson et al., 1997). Furthermore, in this study, the sensitivity of efferent-mediated excitation in CD afferents to varenicline, SazA, and 5-iodo was also consistent with $\alpha 4 \beta 2$ nAChR pharmacology (Mukhin et al., 2000; Coe et al., 2005; Xiao et al., 2006; Zwart et al., 2008). However, since $\alpha 6 \beta 2^{*}$ nAChRs also exhibit a similar pharmacological profile (Capelli et al., 2011; Quik and Wonnacott, 2011), we used the selective antagonists $\alpha$-CtxMII and bPiDDB (McIntosh et al., 2004; Rahman et al., 2008) to demonstrate that efferentmediated excitation in turtle CD afferents likely involves $\alpha 6 \beta 2^{*}$ nAChRs.

Three further considerations are worth mentioning here. First, $\alpha$-CtxMII is a potent antagonist of $\alpha 6 \beta 2^{\star}$ as well as $\alpha 3 \beta 2^{*}$ nAChRs (Cartier et al., 1996; Kuryatov et al., 2000; McIntosh et al., 2004). Although the $\alpha 3$ and $\beta 2$ subunits are expressed by vestibular ganglia (Zoli et al., 1995; Hiel et al., 1996; Anderson et al., 1997), the estimated $\mathrm{IC}_{50}$ values for $\mathrm{DH} \beta \mathrm{E}$ and $\mathrm{bPiDDB}$ in blocking $\alpha 3 \beta 2^{\star}$ nAChRs are in the micromolar range, suggesting that this subclass of nAChRs is unlikely to account for the $\alpha$-CtxMII sensitivity of efferent-mediated excitation in turtle CD afferents (Chavez-Noriega et al., 1997; Endo et al., 2005; Papke et al., 2008; Rahman et al., 2008). One note of caution in making the argument for $\alpha 6 \beta 2^{\star}$ over $\alpha 3 \beta 2^{\star}$ is that it is predicated on turtle and mammalian $\alpha 3 \beta 2^{\star}$ nAChRs having comparable pharmacological profiles. Further experimentation with selective $\alpha 6 \beta 2^{\star}$ $\mathrm{nAChR}$ antagonists may yield additional clarification regarding the involvement of $\alpha 3 \beta 2^{\star}$ nAChRs (Dowell et al., 2003; Pucci et al., 2011). Second, measuring high-affinity binding of $\alpha$-CtxMII in the brains of genetically modified mice, where specific nAChR subunits have been deleted, has revealed that $\alpha 6 \beta 2^{\star} \mathrm{nAChRs}$ can coassemble with $\alpha 3, \alpha 4$, and $\beta 3$ subunits to form multiple nAChR populations (Champtiaux et al., 2003; Salminen et al., 
2004, 2007). Whether efferent-mediated excitation of CD afferents in turtle is driven by multiple populations of $\alpha 6 \beta 2^{\star} \mathrm{nAChRs}$ is unknown, but IHC and ISH data regarding the expression of these other subunits in mammalian and turtle vestibular ganglia suggest such combinations may exist (Hiel et al., 1996; Anderson et al., 1997). Alternatively, $\alpha 4 \beta 2^{*}$ (non- $\alpha 6$ ) nAChRs might also exist on CD afferents and account for the $\sim 20 \%$ of efferent-mediated excitation in CD afferents unaffected by $\alpha$-CtxMII (Table 2).

\section{Distinguishing calyx from dimorphic afferents}

Although calyx and dimorphic afferents innervate type I hair cells, dimorphic afferents differ anatomically by also giving rise to bouton endings that synapse on type II hair cells (Fernández et al., 1988, 1995; Brichta and Goldberg, 2000a; Haque et al., 2006). In mammalian cristae, calyx afferents can be distinguished physiologically from neighboring dimorphic afferents by assessing discharge regularity and the gain and phase of each afferent's response to sinusoidal vestibular stimuli (Baird et al., 1988; Lysakowski et al., 1995). In turtle cristae, however, calyx and dimorphic afferents are indistinguishable using any of the aforementioned physiological properties, thus providing the previous rationale for placing both calyx and dimorphic afferents in a single CD category (Brichta and Goldberg, 2000a). This study shows for the first time that efferent actions on type II hair cells can be pharmacologically isolated and used to distinguish dimorphic from calyx afferents. Since dimorphic and BM afferents overlap in their innervation of type II hair cells in the CZ (Fig. 1, top), we predicted that efferentmediated responses in dimorphic afferents should resemble those in BM afferents, once nAChRs on the dimorphic afferent were blocked. Consistent with such predictions, selective blockade of $\alpha 6 \beta 2^{*} \mathrm{nAChRs}$ in a subset of recordings from $\mathrm{CD}$ afferents revealed a mixed inhibitory-excitatory response that was associated with parallel changes in transmitter release and blocked by ICS or $\alpha$-CtxRgIA. The superimposition of PIE likely explains the secondary excitatory phase in some CD afferents and thus it may also be used to define those units as dimorphic.

A decrease in ensemble variance during efferent stimulation, which has been a reliable indicator of efferent-mediated effects on type II hair cells innervating BT/BM afferents (Holt et al., 2006 b), was also observed in approximately one-third of our intracellular recordings from CD afferents. Of the three efferent targets (i.e., type II hair cell, bouton afferent, or calyx afferent), the variance decrease implicated the involvement of inhibitory efferent synapses on type II hair cells innervating the same CD afferent. As for the efferent-mediated increase in ensemble variances, we suspect that stems from excitatory nAChRs on type II hair cells, although our current pharmacological observations cannot eliminate the possibility that such variance change may be related to an increase in transmitter release from type I hair cells. Admittedly, it is difficult to understand how efferent stimulation would promote transmitter release from type I hair cells given the lack of direct efferent synapses (Holt et al., 2006b). Further experiments with glutamate receptor antagonists should resolve whether variance increases are associated with an enhancement of transmitter release (Holt et al., 2006a,b, 2007). Although we do not have direct evidence that nAChRs other than $\alpha 9 \alpha 10$ nAChRs exist on turtle type II hair cells, there is strong evidence for such receptors in frogs (Holt et al., 2003). Like pharmacological studies in turtle, those in frog have shown that efferent-mediated inhibition of afferent discharge is initiated by the activation of $\alpha 9 \alpha 10$ nAChRs, whereas efferent-mediated excitation is mediated by a group of nAChRs selectively activated by DMPP and insensitive to $\alpha 9 \alpha 10 \mathrm{nAChRs}$ antagonists (Bernard et al., 1985;
Holt et al., 2003). Our immunohistochemistry also suggests that $\alpha 4$ and $\beta 2 \mathrm{nAChR}$ subunits might be expressed by type II hair cells near the planum. Perhaps the CD_E category represents dimorphic afferents innervating type II hair cells near the planum. The functional significance of having distinct nAChRs in specific cellular locations is likely tied to their electrophysiological properties, including activation and desensitization kinetics, ACh sensitivity, and calcium permeability. While these have been characterized for $\alpha 9 \alpha 10$, such data regarding afferent nAChRs are currently lacking.

\section{Implications for mammalian efferent responses}

Mammalian vestibular afferents are invariably excited by efferent stimulation (Goldberg and Fernández, 1980; McCue and Guinan, 1994; Marlinski et al., 2004; Schneider et al., 2013). In agreement with the pharmacological and morphological data presented in this study, RT-PCR and ISH studies implicate a number of nAChR subunits in primary vestibular neurons, including $\alpha 6, \alpha 4$, and $\beta 2$, but not $\alpha 9$ or $\alpha 10$ (Wackym et al., 1995; Hiel et al., 1996; Anderson et al., 1997; Elgoyhen et al., 2001). However, $\alpha 9$ and $\alpha 10 \mathrm{nAChR}$ subunits are expressed in the hair cell layer, and are functionally linked to SK channels in mammalian type II hair cells (Hiel et al., 1996; Anderson et al., 1997; Elgoyhen et al., 2001; Zhou et al., 2013; Yu et al., 2014). Like observations related to turtle, these observations suggest that efferent-mediated inhibitory effects are also present but may be masked by efferentmediated excitation. The panel of cholinergic compounds identified in this study should be useful in parsing out the different efferent synaptic mechanisms in mammals.

\section{References}

Anderson AD, Troyanovskaya M, Wackym PA (1997) Differential expression of $\alpha 2-7, \alpha 9$, and $\beta 2-4$ nicotinic acetylcholine receptor subunit mRNA in the vestibular end-organs and Scarpa's ganglia of the rat. Brain Res 778:409-413. CrossRef Medline

Ayers JT, Dwoskin LP, Deaciuc AG, Grinevich VP, Zhu J, Crooks PA (2002) bis-Azaaromatic quaternary ammonium analogues: ligands for alpha4beta2* and alpha7 ${ }^{\star}$ subtypes of neuronal nicotinic receptors. Bioorg Med Chem Lett 12:3067-3071. CrossRef Medline

Azam L, McIntosh JM (2012) Molecular basis for the differential sensitivity of rat and human $\alpha 9 \alpha 10 \mathrm{nAChRs}$ to $\alpha$-conotoxin RgIA. J Neurochem 122:1137-1144. CrossRef Medline

Baird RA, Desmadryl G, Fernández C, Goldberg JM (1988) The vestibular nerve of the chinchilla. II. Relation between afferent response properties and peripheral innervation patterns in the semicircular canals. J Neurophysiol 60:182-203. Medline

Bernard C, Cochran SL, Precht W (1985) Presynaptic actions of cholinergic agents upon the hair cell-afferent fiber synapse in the vestibular labyrinth of the frog. Brain Res 338:225-236. CrossRef Medline

Brichta AM, Goldberg JM (2000a) Morphological identification of physiologically characterized afferents innervating the turtle posterior crista. J Neurophysiol 83:1202-1223. Medline

Brichta AM, Goldberg JM (2000b) Responses to efferent activation and excitatory response-intensity relations of turtle posterior-crista afferents. J Neurophysiol 83:1224-1242. Medline

Brichta AM, Peterson EH (1994) Functional architecture of vestibular primary afferents from the posterior semicircular canal of a turtle, Pseudemys (Trachemys) scripta elegans. J Comp Neurol 344:481-507. CrossRef Medline

Briggs CA, McKenna DG (1998) Activation and inhibition of the human alpha7 nicotinic acetylcholine receptor by agonists. Neuropharmacology 37:1095-1102. CrossRef Medline

Capelli AM, Castelletti L, Chen YH, Van der Keyl H, Pucci L, Oliosi B, Salvagno C, Bertani B, Gotti C, Powell A, Mugnaini M (2011) Stable expression and functional characterization of a human nicotinic acetylcholine receptor with $\alpha 6 \beta 2$ properties: discovery of selective antagonists. Br J Pharmacol 163:313-329. CrossRef Medline

Carbone AL, Moroni M, Groot-Kormelink PJ, Bermudez I (2009) Pentam- 
eric concatenated (alpha4)(2)(beta2)(3) and (alpha4)(3)(beta2)(2) nicotinic acetylcholine receptors: subunit arrangement determines functional expression. Br J Pharmacol 156:970-981. CrossRef Medline

Cartier GE, Yoshikami D, Gray WR, Luo S, Olivera BM, McIntosh JM (1996) A new alpha-conotoxin which targets alpha3beta2 nicotinic acetylcholine receptors. J Biol Chem 271:7522-7528. CrossRef Medline

Champtiaux N, Gotti C, Cordero-Erausquin M, David DJ, Przybylski C, Léna C, Clementi F, Moretti M, Rossi FM, Le Novère N, McIntosh JM, Gardier AM, Changeux JP (2003) Subunit composition of functional nicotinic receptors in dopaminergic neurons investigated with knock-out mice. J Neurosci 23:7820-7829. Medline

Chavez-Noriega LE, Crona JH, Washburn MS, Urrutia A, Elliott KJ, Johnson EC (1997) Pharmacological characterization of recombinant human neuronal nicotinic acetylcholine receptors $\mathrm{h}$ alpha 2 beta 2 , h alpha 2 beta 4 , h alpha 3 beta 2, h alpha 3 beta 4 , h alpha 4 beta 2, h alpha 4 beta 4 and $\mathrm{h}$ alpha 7 expressed in Xenopus oocytes. J Pharmacol Exp Ther 280:346356. Medline

Coe JW, Brooks PR, Vetelino MG, Wirtz MC, Arnold EP, Huang J, Sands SB, Davis TI, Lebel LA, Fox CB, Shrikhande A, Heym JH, Schaeffer E, Rollema H, Lu Y, Mansbach RS, Chambers LK, Rovetti CC, Schulz DW, Tingley FD 3rd, O’Neill BT (2005) Varenicline: an alpha4beta2 nicotinic receptor partial agonist for smoking cessation. J Med Chem 48:3474-3477. CrossRef Medline

Dailey SH, Wackym PA, Brichta AM, Gannon PJ, Popper P (2000) Topographic distribution of nicotinic acetylcholine receptors in the cristae of a turtle. Hear Res 141:51-56. CrossRef Medline

Dowell C, Olivera BM, Garrett JE, Staheli ST, Watkins M, Kuryatov A, Yoshikami D, Lindstrom JM, McIntosh JM (2003) $\alpha$-Conotoxin PIA is selective for $\alpha 6$ subunit-containing nicotinic acetylcholine receptors. J Neurosci 23:8445-8452. Medline

Dwoskin LP, Wooters TE, Sumithran SP, Siripurapu KB, Joyce BM, Lockman PR, Manda VK, Ayers JT, Zhang Z, Deaciuc AG, McIntosh JM, Crooks PA, Bardo MT (2008) N, N'-alkane-diyl-bis-3-picoliniums as nicotinic receptor antagonists: inhibition of nicotine-evoked dopamine release and hyperactivity. J Pharmacol Exp Ther 326:563-576. CrossRef Medline

Elgoyhen AB, Johnson DS, Boulter J, Vetter DE, Heinemann S (1994) Alpha 9: an acetylcholine receptor with novel pharmacological properties expressed in rat cochlear hair cells. Cell 79:705-715. CrossRef Medline

Elgoyhen AB, Vetter DE, Katz E, Rothlin CV, Heinemann SF, Boulter J (2001) Alpha10: a determinant of nicotinic cholinergic receptor function in mammalian vestibular and cochlear mechanosensory hair cells. Proc Natl Acad Sci U S A 98:3501-3506. CrossRef Medline

Ellison M, Haberlandt C, Gomez-Casati ME, Watkins M, Elgoyhen AB, McIntosh JM, Olivera BM (2006) Alpha-RgIA: a novel conotoxin that specifically and potently blocks the alpha9alpha10 nAChR. Biochemistry 45:1511-1517. CrossRef Medline

Endo T, Yanagawa Y, Obata K, Isa T (2005) Nicotinic acetylcholine receptor subtypes involved in facilitation of GABAergic inhibition in mouse superficial superior colliculus. J Neurophysiol 94:3893-3902. CrossRef Medline

Evans NM, Bose S, Benedetti G, Zwart R, Pearson KH, McPhie GI, Craig PJ, Benton JP, Volsen SG, Sher E, Broad LM (2003) Expression and functional characterisation of a human chimeric nicotinic receptor with alpha6beta4 properties. Eur J Pharmacol 466:31-39. CrossRef Medline

Fayyazuddin A, Brichta AM, Art JJ (1991) Organization of eighth nerve efferents in the turtle, Pseudemys scripta. Soc Neurosci Abstr 17:312.

Fernández C, Baird RA, Goldberg JM (1988) The vestibular nerve of the chinchilla. I. Peripheral innervation patterns in the horizontal and superior semicircular canals. J Neurophysiol 60:167-181. Medline

Fernández C, Lysakowski A, Goldberg JM (1995) Hair cell counts and afferent innervation patterns in the cristae ampullares of the squirrel monkey with a comparison to the chinchilla. J Neurophysiol 73:1253-1269. Medline

Fuchs PA, Murrow BW (1992) A novel cholinergic receptor mediates inhibition of chick cochlear hair cells. Proc Biol Sci 248:35-40. CrossRef Medline

Fucile S, Sucapane A, Eusebi F (2006) Ca2+ permeability through rat cloned alpha9-containing nicotinic acetylcholine receptors. Cell Calcium 39:349-355. CrossRef Medline

Gerzanich V, Anand R, Lindstrom J (1994) Homomers of alpha 8 and alpha 7 subunits of nicotinic receptors exhibit similar channel but contrasting binding site properties. Mol Pharmacol 45:212-220. Medline

Goldberg JM, Fernández C (1980) Efferent vestibular system in the squirrel monkey: anatomical location and influence on afferent activity. J Neurophysiol 43:986-1025. Medline

Goldberg JM, Holt JC (2013) Discharge regularity in the turtle posterior crista: comparisons between experiment and theory. J Neurophysiol 110: 2830-2848. CrossRef Medline

Goutman JD, Fuchs PA, Glowatzki E (2005) Facilitating efferent inhibition of inner hair cells in the cochlea of the neonatal rat. J Physiol 566:49-59. CrossRef Medline

Guth PS, Dunn A, Kronomer K, Norris CH (1994) The cholinergic pharmacology of the frog saccule. Hear Res 75:225-232. CrossRef Medline

Guth PS, Perin P, Norris CH, Valli P (1998) The vestibular hair cells: posttransductional signal processing. Prog Neurobiol 54:193-247. CrossRef Medline

Guth PS, Holt JC, Lioudyno M, McIntosh JM, Hendricson AW, Athas GB, Shipon S (2002) The pharmacology of the non- $\alpha 9 \alpha 10$ nicotinic receptor of hair cells: clues as to subunit composition. Assoc Res Otolaryngol Abstr 480 25:126.

Haque A, Huss D, Dickman JD (2006) Afferent innervation patterns of the pigeon horizontal crista ampullaris. J Neurophysiol 96:3293-3304. CrossRef Medline

Harvey SC, Luetje CW (1996) Determinants of competitive antagonist sensitivity on neuronal nicotinic receptor $\beta$ subunits. J Neurosci 16:37983806. Medline

Harvey SC, McIntosh JM, Cartier GE, Maddox FN, Luetje CW (1997) Determinants of specificity for alpha-conotoxin MII on alpha3beta2 neuronal nicotinic receptors. Mol Pharmacol 51:336-342. Medline

Hasson T, Gillespie PG, Garcia JA, MacDonald RB, Zhao Y, Yee AG, Mooseker MS, Corey DP (1997) Unconventional myosins in inner-ear sensory epithelia. J Cell Biol 137:1287-1307. CrossRef Medline

Hiel H, Elgoyhen AB, Drescher DG, Morley BJ (1996) Expression of nicotinic acetylcholine receptor mRNA in the adult rat peripheral vestibular system. Brain Res 738:347-352. CrossRef Medline

Highstein SM, Baker R (1985) Action of the efferent vestibular system on primary afferents in the toadfish, Opsanus tau. J Neurophysiol 54:370 384. Medline

Holt JC, Lioudyno M, Athas G, Garcia MM, Perin P, Guth PS (2001) The effect of proteolytic enzymes on the alpha9-nicotinic receptor-mediated response in isolated frog vestibular hair cells. Hear Res 152:25-42. CrossRef Medline

Holt JC, Lioudyno M, Guth PS (2003) A pharmacologically distinct nicotinic ACh receptor is found in a subset of frog semicircular canal hair cells. J Neurophysiol 90:1526-1536. CrossRef Medline

Holt JC, Xue JT, Brichta AM, Goldberg JM (2006a) Transmission between type II hair cells and bouton afferents in the turtle posterior crista. J Neurophysiol 95:428-452. Medline

Holt JC, Lysakowski A, Goldberg JM (2006b) Mechanisms of efferentmediated responses in the turtle posterior crista. J Neurosci 26:1318013193. CrossRef Medline

Holt JC, Chatlani S, Lysakowski A, Goldberg JM (2007) Quantal and nonquantal transmission in calyx-bearing fibers of the turtle posterior crista. J Neurophysiol 98:1083-1101. CrossRef Medline

Holt JC, Lysakowski A, Goldberg JM (2011) Chapter 6: efferent vestibular system. In: Springer handbook of auditory research: auditory and vestibular efferents (Ryugo DK, Fay RR, Popper AN, eds), pp 135-186. New York: Springer.

Huwe J, Williams B, Rowe M, Peterson E (2011) Afferent terminal arbor structure in turtle utricle. Assoc Res Otolaryngol Abstr 253 34:86.

Ishiyama A, Lopez I, Wackym PA (1995) Distribution of efferent cholinergic terminals and alpha-bungarotoxin binding to putative nicotinic acetylcholine receptors in the human vestibular end-organs. Laryngoscope 105:1167-1172. CrossRef Medline

Iturriaga-Vásquez P, Carbone A, García-Beltrán O, Livingstone PD, Biggin PC, Cassels BK, Wonnacott S, Zapata-Torres G, Bermudez I (2010) Molecular determinants for competitive inhibition of alpha4beta2 nicotinic acetylcholine receptors. Mol Pharmacol 78:366-375. CrossRef Medline

Jordan PM, Parks XX, Contini D, Holt JC (2013) A review of synaptic mechanisms of vestibular efferent signaling in turtles: extrapolation to efferent actions in mammals. J Vestib Res 23:161-175. CrossRef Medline

Jositsch G, Papadakis T, Haberberger RV, Wolff M, Wess J, Kummer W (2009) Suitability of muscarinic acetylcholine receptor antibodies for immunohistochemistry evaluated on tissue sections of receptor gene- 
deficient mice. Naunyn Schmiedebergs Arch Pharmacol 379:389-395. CrossRef Medline

Kong WJ, Egg G, Hussl B, Spoendlin H, Schrott-Fischer A (1994) Localization of chat-like immunoreactivity in the vestibular endorgans of the rat. Hear Res 75:191-200. CrossRef Medline

Kong WJ, Cheng HM, van Cauwenberge P (2006) Expression of nicotinic acetylcholine receptor subunit alpha9 in type II vestibular hair cells of rats. Acta Pharmacol Sin 27:1509-1514. CrossRef Medline

Kuryatov A, Olale F, Cooper J, Choi C, Lindstrom J (2000) Human alpha6 AChR subtypes: subunit composition, assembly, and pharmacological responses. Neuropharmacology 39:2570-2590. CrossRef Medline

Luebke AE, Maroni PD, Guth SM, Lysakowski A (2005) Alpha-9 nicotinic acetylcholine receptor subunit immunoreactivity in the rodent vestibular labyrinth. J Comp Neurol 492:323-333. CrossRef Medline

Lustig LR, Hiel H, Fuchs PA (1999) Vestibular hair cells of the chick express the nicotinic acetylcholine receptor subunit alpha 9. J Vestib Res 9:359367. Medline

Lysakowski A, Goldberg JM (1997) A regional ultrastructural analysis of the cellular and synaptic architecture in the chinchilla cristae ampullares. J Comp Neurol 389:419-443. CrossRef Medline

Lysakowski A, Goldberg JM (2004) Morphophysiology of the vestibular periphery. In: The vestibular system (Highstein SM, Popper A, Fay RR, eds), pp 57-152. New York: Springer.

Lysakowski A, Minor LB, Fernández C, Goldberg JM (1995) Physiological identification of morphologically distinct afferent classes innervating the cristae ampullares of the squirrel monkey. J Neurophysiol 73:1270-1281. Medline

Marks MJ, Meinerz NM, Brown RW, Collins AC (2010) ${ }^{86} \mathrm{Rb}^{+}$efflux mediated by alpha4beta $2^{*}$-nicotinic acetylcholine receptors with high and low-sensitivity to stimulation by acetylcholine display similar agonistinduced desensitization. Biochem Pharmacol 80:1238-1251. CrossRef Medline

Marlinski V, Plotnik M, Goldberg JM (2004) Efferent actions in the chinchilla vestibular labyrinth. J Assoc Res Otolaryngol 5:126-143. Medline

McClure-Begley TD, Wageman CR, Grady SR, Marks MJ, McIntosh JM, Collins AC, Whiteaker P (2012) A novel $\alpha$-conotoxin MII-sensitive nicotinic acetylcholine receptor modulates [(3) H]-GABA release in the superficial layers of the mouse superior colliculus. J Neurochem 122:48-57. CrossRef Medline

McCue MP, Guinan JJ Jr (1994) Influence of efferent stimulation on acoustically responsive vestibular afferents in the cat. J Neurosci 14:6071-6083. Medline

McIntosh JM, Azam L, Staheli S, Dowell C, Lindstrom JM, Kuryatov A, Garrett JE, Marks MJ, Whiteaker P (2004) Analogs of alpha-conotoxin MII are selective for alpha6-containing nicotinic acetylcholine receptors. Mol Pharmacol 65:944-952. CrossRef Medline

Meredith GE (1988) Comparative view of the central organization of afferent and efferent circuitry for the inner ear. Acta Biol Hung 39:229-249. Medline

Mogg AJ, Whiteaker P, McIntosh JM, Marks M, Collins AC, Wonnacott S (2002) Methyllycaconitine is a potent antagonist of alpha-conotoxinMII-sensitive presynaptic nicotinic acetylcholine receptors in rat striatum. J Pharmacol Exp Ther 302:197-204. CrossRef Medline

Monk G, Peterson EH (1995) Calretinin is not specific for calyceal afferents in the semicircular canals of Pseudemys scripta. Soc Neurosci Abstr 21:918.

Moser N, Mechawar N, Jones I, Gochberg-Sarver A, Orr-Urtreger A, Plomann M, Salas R, Molles B, Marubio L, Roth U, Maskos U, WinzerSerhan U, Bourgeois JP, Le Sourd AM, De Biasi M, Schröder H, Lindstrom J, Maelicke A, Changeux JP, Wevers A (2007) Evaluating the suitability of nicotinic acetylcholine receptor antibodies for standard immunodetection procedures. J Neurochem 102:479-492. CrossRef Medline

Mukhin AG, Gündisch D, Horti AG, Koren AO, Tamagnan G, Kimes AS, Chambers J, Vaupel DB, King SL, Picciotto MR, Innis RB, London ED (2000) 5-Iodo-A-85380, an alpha4beta2 subtype-selective ligand for nicotinic acetylcholine receptors. Mol Pharmacol 57:642-649. Medline

Ohno K, Takeda N, Kiyama H, Kato H, Fujita S, Matsunaga T, Tohyama M (1993) Synaptic contact between vestibular afferent nerve and cholinergic efferent terminal: its putative mediation by nicotinic receptors. Brain Res Mol Brain Res 18:343-346. CrossRef Medline

Oliver D, Klöcker N, Schuck J, Baukrowitz T, Ruppersberg JP, Fakler B (2000) Gating of $\mathrm{Ca}^{2+}$-activated $\mathrm{K}^{+}$channels controls fast inhibitory synaptic transmission at auditory outer hair cells. Neuron 26:595-601. CrossRef Medline

Papke RL, Dwoskin LP, Crooks PA, Zheng G, Zhang Z, McIntosh JM, Stokes C (2008) Extending the analysis of nicotinic receptor antagonists with the study of alpha6 nicotinic receptor subunit chimeras. Neuropharmacology 54:1189-1200. CrossRef Medline

Papke RL, Trocmé-Thibierge C, Guendisch D, Al Rubaiy SA, Bloom SA (2011) Electrophysiological perspectives on the therapeutic use of nicotinic acetylcholine receptor partial agonists. J Pharmacol Exp Ther 337: 367-379. CrossRef Medline

Peng C, Stokes C, Mineur YS, Picciotto MR, Tian C, Eibl C, Tomassoli I, Guendisch D, Papke RL (2013) Differential modulation of brain nicotinic acetylcholine receptor function by cytisine, varenicline, and two novel bispidine compounds: emergent properties of a hybrid molecule. J Pharmacol Exp Ther 347:424-437. CrossRef Medline

Popper P, Ishiyama A, Lopez I, Wackym PA (2002) Calcitonin gene-related peptide and choline acetyltransferase colocalization in the human vestibular periphery. Audiol Neurootol 7:298-302. CrossRef Medline

Pucci L, Grazioso G, Dallanoce C, Rizzi L, De Micheli C, Clementi F, Bertrand S, Bertrand D, Longhi R, De Amici M, Gotti C (2011) Engineering of $\alpha$-conotoxin MII-derived peptides with increased selectivity for native $\alpha 6 \beta 2^{\star}$ nicotinic acetylcholine receptors. FASEB J 25:3775-3789. CrossRef Medline

Pujol R, Pickett SB, Nguyen TB, Stone JS (2014) Large basolateral processes on type II hair cells are novel processing units in mammalian vestibular organs. J Comp Neurol 522:3141-3159. CrossRef Medline

Purcell IM, Perachio AA (1997) Three-dimensional analysis of vestibular efferent neurons innervating semicircular canals of the gerbil. J Neurophysiol 78:3234-3248. Medline

Quik M, Wonnacott S (2011) $\alpha 6 \beta 2^{*}$ and $\alpha 4 \beta 2^{\star}$ nicotinic acetylcholine receptors as drug targets for Parkinson's disease. Pharmacol Rev 63:938 966. CrossRef Medline

Rahman S, Zhang Z, Papke RL, Crooks PA, Dwoskin LP, Bardo MT (2008) Region-specific effects of N, $\mathrm{N}^{\prime}$-dodecane-1,12-diyl-bis-3-picolinium dibromide on nicotine-induced increase in extracellular dopamine in vivo. Br J Pharmacol 153:792-804. CrossRef Medline

Rice SO (1944) Mathematical analysis of random noise. Bell Sys Tech J 23: 282-332. CrossRef

Rossi ML, Prigioni I, Valli P, Casella C (1980) Activation of the efferent system in the isolated frog labyrinth: effects on the afferent EPSPs and spike discharge recorded from single fibres of the posterior nerve. Brain Res 185:125-137. CrossRef Medline

Rossi ML, Martini M, Pelucchi B, Fesce R (1994) Quantal nature of synaptic transmission at the cytoneural junction in the frog labyrinth. J Physiol 478:17-35. CrossRef Medline

Rothlin CV, Katz E, Verbitsky M, Elgoyhen AB (1999) The alpha9 nicotinic acetylcholine receptor shares pharmacological properties with type A gamma-aminobutyric acid, glycine, and type 3 serotonin receptors. Mol Pharmacol 55:248-254. Medline

Rothlin CV, Lioudyno MI, Silbering AF, Plazas PV, Casati ME, Katz E, Guth PS, Elgoyhen AB (2003) Direct interaction of serotonin type 3 receptor ligands with recombinant and native alpha 9 alpha 10-containing nicotinic cholinergic receptors. Mol Pharmacol 63:1067-1074. CrossRef Medline

Salminen O, Murphy KL, McIntosh JM, Drago J, Marks MJ, Collins AC, Grady SR (2004) Subunit composition and pharmacology of two classes of striatal presynaptic nicotinic acetylcholine receptors mediating dopamine release in mice. Mol Pharmacol 65:1526-1535. CrossRef Medline

Salminen O, Drapeau JA, McIntosh JM, Collins AC, Marks MJ, Grady SR (2007) Pharmacology of alpha-conotoxin MII-sensitive subtypes of nicotinic acetylcholine receptors isolated by breeding of null mutant mice. Mol Pharmacol 71:1563-1571. CrossRef Medline

Sans A, Highstein SM (1984) New ultrastructural features in the vestibular labyrinth of the toadfish, Opsanus tau. Brain Res 308:191-195. CrossRef Medline

Schneider GT, Plotnik M, Holt JC (2013) Afferent responses to efferent stimulation in the murine vestibular system. Assoc Res Otolaryngol Abstr $36: 122$.

Sgard F, Charpantier E, Bertrand S, Walker N, Caput D, Graham D, Bertrand D, Besnard F (2002) A novel human nicotinic receptor subunit, alpha10, that confers functionality to the alpha9-subunit. Mol Pharmacol 61:150-159. CrossRef Medline 
Smith AM, Pivavarchyk M, Wooters TE, Zhang Z, Zheng G, McIntosh JM, Crooks PA, Bardo MT, Dwoskin LP (2010) Repeated nicotine administration robustly increases bPiDDB inhibitory potency at alpha6beta2containing nicotinic receptors mediating nicotine-evoked dopamine release. Biochem Pharmacol 80:402-409. CrossRef Medline

Smith CA, Rasmussen GL (1968) Nerve endings in the maculae and cristae of the chinchilla vestibule, with a special reference to the efferents. The third symposium on the role of the vestibular organs in space exploration. NASA SP-152, pp 183-201. Washington, DC: U.S. Government Printing Office.

Sugai T, Sugitani M, Ooyama H (1991) Effects of activation of the divergent efferent fibers on the spontaneous activity of vestibular afferent fibers in the toad. Jpn J Physiol 41:217-232. CrossRef Medline

Sugai T, Yano J, Sugitani M, Ooyama H (1992) Actions of cholinergic agonists and antagonists on the efferent synapse in the frog sacculus. Hear Res 61:56-64. CrossRef Medline

Verbitsky M, Rothlin CV, Katz E, Elgoyhen AB (2000) Mixed nicotinicmuscarinic properties of the alpha9 nicotinic cholinergic receptor. Neuropharmacol 39:2515-2524. CrossRef

Vincler M, Wittenauer S, Parker R, Ellison M, Olivera BM, McIntosh JM (2006) Molecular mechanism for analgesia involving specific antagonism of alpha9alpha10 nicotinic acetylcholine receptors. Proc Natl Acad Sci U S A 103:17880-17884. CrossRef Medline

Wackym PA, Popper P, Lopez I, Ishiyama A, Micevych PE (1995) Expression of alpha 4 and beta 2 nicotinic acetylcholine receptor subunit mRNA and localization of alpha-bungarotoxin binding proteins in the rat vestibular periphery. Cell Biol Int 19:291-300. CrossRef Medline
Weisstaub N, Vetter DE, Elgoyhen AB, Katz E (2002) The alpha9alpha10 nicotinic acetylcholine receptor is permeable to and is modulated by divalent cations. Hear Res 167:122-135. CrossRef Medline

Xiao Y, Fan H, Musachio JL, Wei ZL, Chellappan SK, Kozikowski AP, Kellar KJ (2006) Sazetidine-A, a novel ligand that desensitizes alpha4beta 2 nicotinic acetylcholine receptors without activating them. Mol Pharmacol 70:1454-1460. CrossRef Medline

Yu Z, Sadeghi S, McIntosh M, Glowatzki E (2014) Acetylcholine-mediated ionotropic currents in vestibular calyx afferents and type II hair cells. Assoc Res Otolaryngol Abstr 213 37:114.

Zhou T, Wang Y, Guo CK, Zhang WJ, Yu H, Zhang K, Kong WJ (2013) Two distinct channels mediated by $\mathrm{m} 2 \mathrm{mAChR}$ and $\alpha 9 \mathrm{nAChR}$ co-exist in type II vestibular hair cells of guinea pig. Int J Mol Sci 14:8818-8831. CrossRef Medline

Zoli M, Le Novère N, Hill JA Jr, Changeux JP (1995) Developmental regulation of nicotinic ACh receptor subunit mRNAs in the rat central and peripheral nervous systems. J Neurosci 15:1912-1939. Medline

Zwart R, Carbone AL, Moroni M, Bermudez I, Mogg AJ, Folly EA, Broad LM, Williams AC, Zhang D, Ding C, Heinz BA, Sher E (2008) Sazetidine-A is a potent and selective agonist at native and recombinant alpha 4 beta 2 nicotinic acetylcholine receptors. Mol Pharmacol 73:1838-1843. CrossRef Medline

Zwart R, Strotton M, Ching J, Astles PC, Sher E (2014) Unique pharmacology of heteromeric $\alpha 7 \beta 2$ nicotinic acetylcholine receptors expressed in Xenopus laevis oocytes. Eur J Pharmacol 726:77-86. CrossRef Medline 